\title{
A IGREJA DE SÃO MIGUEL DAS MISSõES
}

\author{
Prof. Arq. LUCAS MAYERHOFER
}

\section{I - Estabilização das ruinas da Igreja de São Miguel das Missōes (*)}

"Bianchi, Ioann. Andreas, Coad. 1677-1740

1716 "A di 1 febr. 1716, fu abbracciato per Fratello coadiutore Giov. Andrea Bianchi Milanese, il quale porto seco un mantello di panno turchino, un giustacore, camisciola, calzoni di panno celesti tanto usato, una camisciola di riverscio rosso, un capello, una perucha, un paro di calzette di seta negro, un paro di lana, un paro di filo, un paro di scarpe colle fibbie di ferro, 3 camiscie, 3 fazoletti, due corvatte, due berettini di notte Io

(*) Por sugestāo do Professor Arquiteto Eduardo Augusto Kneese de Mello, responsável pelo setor de Arte e Arquitetura do «Curso sóbre o Rlo Grande do Sul», promovido pelo Instituto de Estudos Brasilelros da Universidade de São Paulo, fü convidado pelo Diretor, Professor $\mathrm{Dr}$. José Aderaldo Castello, a chamar a atencūo dos estudiosos para um trabalho que realizamos de 1938 a 1940: a estabilizacăo das ruinas da igreja de Săo Miguel das Missões, projetada e construida pelo arquiteto milanes Gian Battista Primoli.

Era uma das maiores Igrejas do Brasil, medindo 45 metros de extensão na fachada principal e 80 metros da frente aos fundos; suas torres tinham paredes de 3 metros de espessura e 23 metros de altura. Totalmente construlda de pedra até a altura dos tetos, tinha seus paramentos esculpidos, tanto interna como externamente, com modenatura e decoracāo barrôcas.

O abandono em que ficou o templo após a expulsão dos jesuitas, em 1768, fol responsável pelo estado em que se encontrava em 1938, quando o Governo Brasileiro resolveu preservá-1o da destruicăo total. Os tetos haviam desaparecido e as paredes em grande parte desaprumadas ameacavam desmoronamento, mas o que a todos preocupava era a situacăo da tôrre, que acusava um desaprumo de $1,50 \mathrm{~m}$. A estabillizacão das ruinas fol-nos então conflada pelo Servico do Património Hilstó: rico e Artistico Nacional.

Estudando detidamente o monumento, alvitramos para a consolidacāo da torre - processo da demollcão prévia e reconstrucāo sobre novas fundacóes.

Depols de termos feito o levantamento das ruinas, numeramos com tinta a óleo, pedra por pedra, todos os paramentos a demolir, consignando essa numeracão em desenhos que foram guardados cuidadosamente. Só após essas precaucōes, fol felta a demolicão. Na reconstrucũo, a numeraçáo feita por ocasiáo do levantamento fol rigorosamente observada.

Os pormenores dêsse trabalho, bem como a reconstituicão do Povo de São Miguel, de que nos restam uma poucas muralhas além das ruinas majestosas da igreja, são o objeto da presente comunicacão. 
Gio Andrea Bianchi" In margine: "3 Ag. 1716 parti da Roma per il Paraguay, per Firenze e Pisa etc" Rom. 175 p. 67 Ann. 1735. Colleg. maxim. Cordubense. Fr. Andreas Bianchi Architectus, Patria Campione in Insubria, natus 25 Novembris 1677, ingressus (in Societatem Iesu) 1 Februarii 1716, Coadiutor formatus 2 Februarii 1728 Catal. Parag. 6 fol. 177 v. Andread Blanqui (mortus) in Collegio Cordubensi 25 Decembris 1740 Cat. Parag. 6 f. 245

Primoli, Giovan Battista, Coad.

Fr. Yoannes Baptista Primoli, Architectus, Patria Mediolanensis, natus 10 Octobris 1679, ingressus (in Societatem Yesu) 11 Januarii 1716, Coadiutor formatus 3 Decembris 1727 Catal. Parag. 6 fol. 263 Fr. Yoannes Baptista Primoli (mortus) in Oppido Candelariae Missionum 15 Septembris 1747 Ibid. fol. 341"

São apenas êsses os dados do Arquivo Romano da Sociedade de Jesus sôbre dois irmãos jesuitas que dedicaram tôda sua atividade à construçãu nas colônias espanholas da América do Sul.

Os livros italianos de História da Arte não mencionam os dois arquitetos, nem a importante publicação do Govêrno Italiano l'Opera del Genio Italiano $a l l$ Estero faz sôbre êles a menor referência.

No entanto, a obra realizada por Andrea Bianchi e Gian Battista Primoli é notável e projeta bem alto o nome da Arquitetura italiana nas comunidades que se iam construindo do outro lado do Atlântico.

Em nossos dias, historiadores e arquitetos, pesquisando arquivos e estudando os monumentos subsistentes, vêm estabelecendo os elementos para a História da Arquitetura na Sul América. O livro de autoria do Padre Jesuita Guilhermo Furlong - Arquitectos Argentinos durante la dominacion Hispanica faz o inventário dos monumentos edificados pelos arquitetos Andrea Bianchi e Gian Battista Primoli.

Dos monumentos construídos pelas Missōes Jesuiticas na margem oriental do rio Uruguai, as ruínas da Igreja de São Miguel atestam ainda o elevado pađrāo arquitetônico.

Logo de sua formaçāo, o Serviço do Patrimônio Histórico e Artístico Nacional, dirigido pelo eminente brasileiro Rodrigo Mello Franco de Andrade, esforçou-se por preservar da destruição essas ruinas e recolher sob sua proteção grande número de imagens de madeira e pedra, conservadas na regiāo e que se pode, sem favor, comparar à mais expressiva escultura do tempo.

Rodrigo Mello Franco de Andrade recorreu primeiramente aos Serviços de seu assistente técnico no Estado do Rio Grande do Sul, o escritor Augusto Meyer, que apresentou relatório circunstanciado sôbre o assunto, ressaltando o interêsse documentário das ruínas. Em seguida, desejando proceder às 
obras de restauração, encarregou o arquiteto Lúcio Costa de inventariar os elementos subsistentes e tracar o programa dos trabalhos.

A incumbência foi levada a efeito com a seriedade que caracteriza o trabalho do grande arquiteto patricio. Seu relatório, acompanhado de excelente documentação, concluiu pelas seguintes providências:

"1." - As ruínas da igreja de São Miguel, que apresentam grande interêsse como conjunto arquitetônico, deveriam ser amparadas de forma a prevenir o seu total desmoronamento.

"2." - Os fragmentos de Arquitetura e as esculturas encontradas nos sete povos, bem como os que se poderia descobrir em buscas e escavações, mereciam ser recolhidos ao Povo de São Miguel, num museu a ser construido com material das ruinas, senão em as próprias ruinas devidamente abrigadas". Para a construção do museu apresentou Lúcio Costa projeto de grande interêsse.

Nomeado para dirigir o Instituto do Livro, o escritor Augusto Meyer deixou o cargo de Assistente Técnico do Serviço do Patrimônio Histórico e Artistico Nacional da $7 .^{\mathrm{a}}$ região, sendo substituido pelo engenheiro e historiador paranaense David Antônio da Silva Carneiro, a quem coube dar andamento aos serviços de proteção das ruinas missioneiras. Seu primeiro cuidado foi proceder a escavaçōes e pesquisas nos diferentes Povos, buscando colhêr elementos porventura soterrados pela destruiçāo dos muros.

A consolidação das ruinas e a construção do Museu foram-me então confiadas.

Iniciei os trabalhos procurando descobrir as causas que provocaram o desequilibrio e danos sofridos pelo monumento para decidir-me sôbre o método a adotar.

Observo que os processos de restauração se confundem com a prática de execução. Não é razoável nem oportuno querer sistematizar nem fixar normas.

Nāo há norma fundamental para restauração. Diante do monumento, êle próprio é o mestre; para quem estuda detidamente um monumento, e o interroga com severidade de historiador, paixão de artista e amor de arquiteto, qualquer restauração se determina particularmente por si mesma.

Quando, em 1938, me foi confiada a incumbência de consolidar as ruinas de São Miguel, a situação do monumento era tal como aparece na foto 1 , da ilustração.

Do grande pórtico da fachada principal restavam apenas as colunas e arcadas laterais, muito tombadas devido à deficiência das fundaçōes, e ainda 
assim incompletas. Colunas, arcadas de frente, frontão e até as pedras do piso haviam sido carregadas, à medida que se ía desmoronando o edifício.

O escoramento anteriormente feito, com trilhos de ferro, nāo impediria com o correr do tempo o seu total desmoronamento. Demoliçāo e reconstrução sôbre novas fundaçōes impunham-se para conservá-lo.

Em volta do pórtico, mas sem apoio nêle, estabelecemos andaimes sòlidamente construidos. Depois de cuidadosamente feito o levantamento do pórtico (foto 2) numeramos tôdas as pedras, divididas em quadras, segundo as alturas, e isso em cada face do pórtico, e guardamos dessa numeração vários desenhos para garantia do serviço, em caso de extravio.

Só após estas precauçōes foi iniciada a demolição.

Terminada esta e abertos os alicerces, verificou-se como certo o nosso prognóstico: as fundações consistiam num aglomerado de pedras roliças, sem a menor amarração; o espaço entre elas era cheio com barro grosseiro. As formigas tinham aberto nesse barro enormes buracos. Além disso, as fundaçōes ocupavam uma largura pouco maior que a espessura das paredes. Quanto a sua profundidade, teria sido suficiente, se bem executada a alvenaria, pois o terreno é firme.

Sôbre êsse solo, estendemos uma camada de concreto, no traço de $1: 3: 4$, e logo após, construímos alicerces de concreto ciclópico, no traço de $1: 4: 7$ + pedra de mão, armados na parte inferior com trilhos de ferro, aproveitados entre aquêles que serviam ao escoramento, e colocados cada $0,20 \mathrm{~m}$.

Sôbre tais alicerces reconstruimos as duas alas do pórtico.

O que a todos preocupava, porém, era a situação da tôrre da igreja, a qual, medindo 23 metros de altura apresentava desaprumo de 1.37 no cunhal $\mathrm{NE}$ e $1.57 \mathrm{~m}$ no cunhal SE. Devido a esta deformação, viam-se no corpo da obra enormes fendas, que aumentavam de importância visto que rachara a massa que os pedreiros haviam empregado anteriormente para remendo.

Pelo modo como se deformou a tôrre, era certo encontrarmos em suas fundaçōes a mesma deficiência que encontramos nas do pórtico. Efetivamente, as fundaçōes daquela assentavam sôbre terreno firme e seria possivel reforçá-los; mas, nas condiçōes em que se encontravam as paredes, o lado esquerdo da tôrre acabaria por desmoronar e qualquer amarração só viria a prejudicar o lado que se mantinha aprumado, pois nenhuma alvenaria trabalha à distensão, máxime esta alvenaria irregular e sem argamassa.

A vista da situação, adotei para consolidaçāo da parte tombada da tôrre o critério de sua demolição prévia a fim de reconstrui-la sôbre novas fundaçōes. 


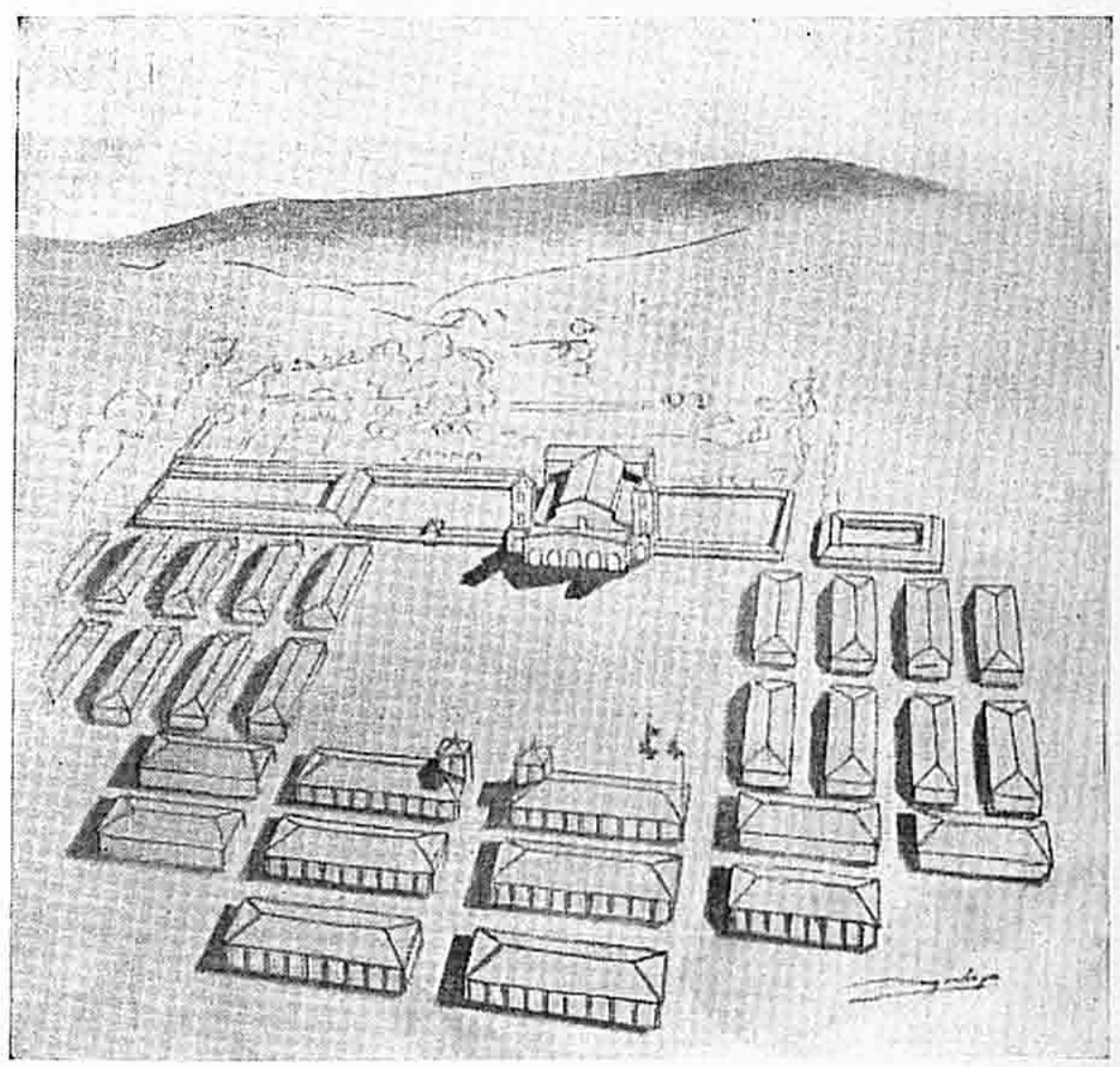

Foto 11 - Reconstituiçõo do Povo de São Miguel. Perspectiva. 
tapando as juntas com massa de cimento e areia, para impedir a infiltração das chuvas.

Em três ângulos encontramos gárgulas (foto 8); um quarto exemplar foi desenterrado ao pé da tôrre. A foto 9 mostra o belo capitel, ornado com representação de fôlhas, flôres e frutas de romã, dispostas como se fôssem de acanto. Terminada a reconstrução, foram retirados os andaimes, trabalho que nos ocupou durante 2 semanas.

Para proteção do corpo da igreja, executamos importante trabalho, compreendendo retirada de troncos e raizes, fechamento de fendas para impedir a infiltração da água e substituição indispensável de algumas pedras.

Fizemos atêrro em rampa em tôda a extensão dos muros, para que a água não venha mais a se estagnar ao longo dêles. Uma das causas de ruína consistia nos muitos buracos cavados ao pé dos muros por pessoas buscando ouro ou reliquias da lendária riqueza dos jesuitas.

No eixo da nave, em todo seu comprimento, construímos um canal coberto para escoamento das águas de chuva. Foi, a nosso ver, a melhor solução para proteger as fundaçōes do corpo da igreja. Completamos êsse serviço pela iniciativa da execução de importante atêrro para encher as bacias e buracos existentes ao longo da nave e colaterais, assim como para obter os caimentos necessários.

A foto 10 mostra a tôrre após sua consolidação.

E com saudades que me recordo do mestre dos meus operários, o $\mathrm{Sr}$. Fernando Hartmann, dedicado e competente auxiliar, que faleceu 2 anos mais tarde, quando trabalhava comigo na estabilização da igreja matriz do Serro, no Estado de Minas Gerais.

Sinto-me feliz por ter conseguido, com resultado satisfatório, a estabilização da tôrre de $\mathrm{S}$. Miguel, utilizando método que ainda não havia sido empregado em nosso pais, e satisfeito com a oportunidade de recordar preocupaçōes, lutas, canseiras, inverno rigoroso, rijo minuano, mas também ocorrências curiosas e o aspecto pitoresco da costa da serra do Rio Grande do Sul.

\section{II - Reconstituição do Povo de São Miguel das Missōes}

\section{a) ORIGENS HUSTORICAS}

No século XVI, o poder e a cultura europeus estenderam-se às Américas; em princípios dos século XVII já os estabelecimentos provisórios passavam a tomar um caráter de permanência, as riquezas das novas terras começavam a 


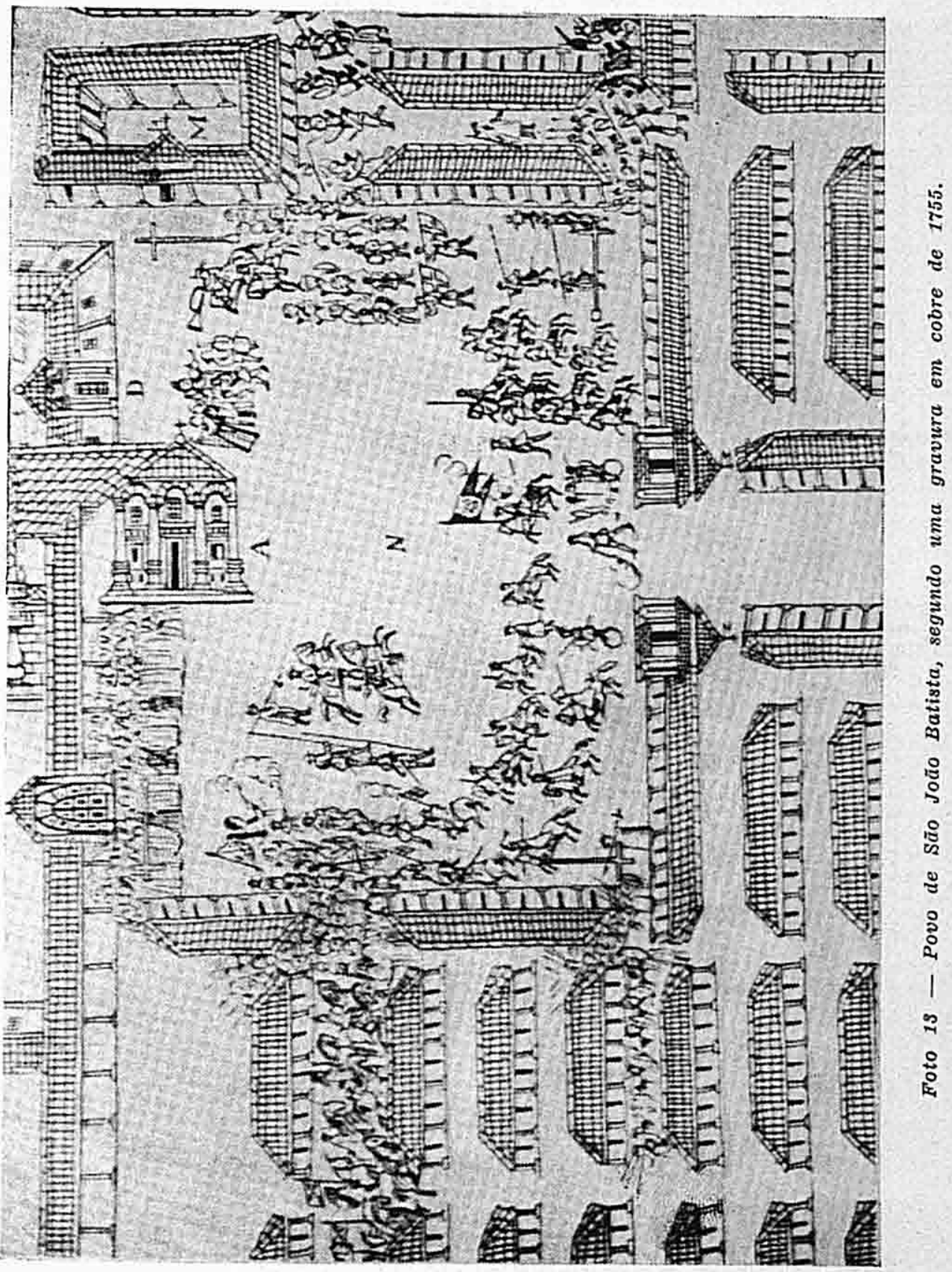


Nóbrega e José de Anchieta conseguindo a pacificação dos tamoios que se haviam aliado a corsários franceses.

Os jesuitas, educados na mais pura moral e com alevantados ideais de humanitarismo, cedo entraram em luta com os plantadores, tendo por objetivo melhorar a situação dos indigenas. Na História do Brasil vemos a cada página fases dessa luta entre os colonos escravizadores dos indios e seus protetores, os jesuítas.

Os soberanos espanhóis compreenderam a impossibilidade de conseguir a catequese dos indios sujeitos aos colonos, obrigados aos mais duros trabalhos, maltratados, e vendo nos senhores da terra o contrário do homem cristão exemplar, que lhes era citado pela doutrina.

Foram, então, criadas as Missōes, isto é, expedições para a catequese no próprio meio indigena, longe do convívio com os brancos, meros caçadores de fortuna.

As primeiras Missōes, acompanhando os indios nômades, alcançaram resultado insignificante. A pregação espiritual, sem a demonstração das vantagens oferecidas pela Civilização Cristā, não bastava para os convencer. Por isso, os jesuitas do Paraguai e Tucuman, convocados em Salta, em 1602, pronunciaram-se todos pela catequese estável.

Adotou-se o sistema das Reduções, isto é, aldeiamentos em que os indios eram conduzidos (reduciret) à fé cristã.

Nas Reduçōes, fixavam-se os indios nômades, sob a direção dos jesuitas, que passavam a reunir nesses estabelecimentos o poder temporal ao espiritual.

Além dos argumentos espirituais, eram oferecidas aos indios as vantagens materiais que pode proporcionar a Civilização: alimentação, abrigo, vestuário e aparelhamento à defesa não deveriam faltar:

"Cuida bem das minhas vaquinhas", dizia o Padre que se ausentava ao substituto, "porque indio sem carne volta para o mato".

Năo se pense, todavia, terem sido fáceis a obra e a existência dos jesuitas. Longe de suas sedes provinciais, lutavam com tôda sorte de dificuldades que sobrepujavam com engenho e coragem. Entre outros obstáculos, tinham que lutar contra o temperamento infantil e bastante instável dos nativos. Acontecia, por vêzes, que, sùbitamente, da noite para o dia, todo um grande trabalho de catequese redundava em fracasso, como em Japeiú, no século XVII, quando precisamente ao inaugurar-se uma nova Redução, os indios declararam sua decisāo de reverter ao modo de vida primitivo. Alegaram êles não querer um Deus que tudo via e de tudo sabia. 


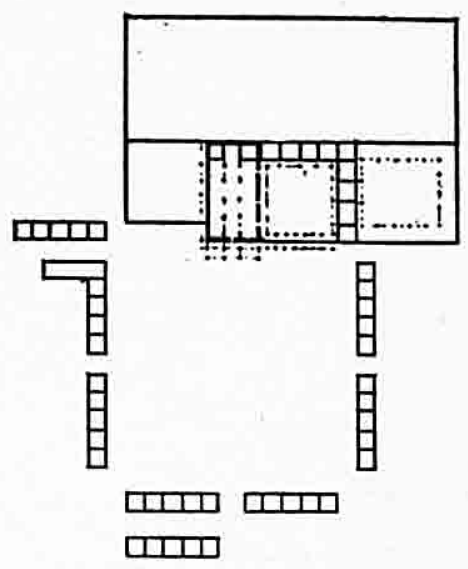

पाDा
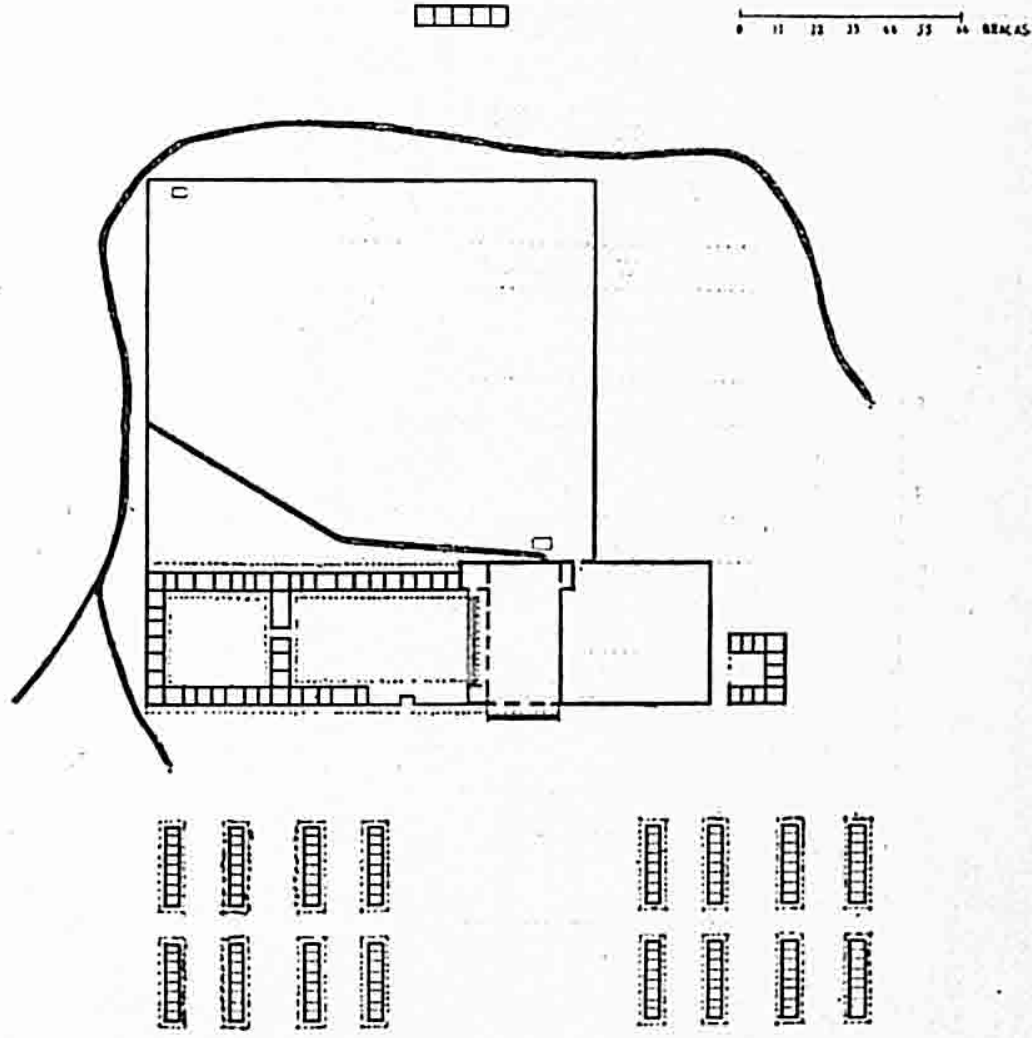

:

: 1

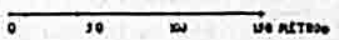


portaram-se para além rio. São Miguel emigrou como as outras, localizando-se nas proximidades de Concepción.

Ai cresceu extraordinàriamente, mas, faltando-lhe terras para sua expansão, trasladou-se em 1687 para situação definitiva, à margem esquerda do rio Uruguai, localizando-se ao norte do rio Piratini, entre as coordenadas de $28^{\circ} 32^{\prime} 36^{\prime \prime}$ de lat. Sul e $323^{\circ} 45^{\prime}$ de long. Leste da ilha do Ferro.

Já então contava o Povo 4.000 almas e era a mais populosa das Missōes.

Como tôdas as outras instituiçōes jesuiticas naquela regiāo, o Povo de São Miguel desenvolveu-se, segundo normas de uma habilidade quase inverossímel, visando ao trabalho coletivo.

E verdade que da Companhia, na Europa, vinham técnicos de tôda espécie, incluindo os que se chamariam hoje especialistas, como cartógrafos, etnólogos, relojoeiros, armeiros, etc. As matérias primas eram, porém, aqui extraidas e aqui também elaborada a ferramenta necessária.

São Miguel possuía uma das mais importantes estâncias de gado da regiāo missioneira, abrangendo quarenta léguas de largura por vinte léguas de comprimento (2), com enormes rebanhos de gado vacum, cavalar e ovelhum, servindo êste de fonte produtora de lã, que era cardada e tecida pelos indios (3).

Desde os seus primórdios, a Missão dedicou particular esfôrço à agricultura, com extensíssimas plantações e colheitas abundantes de erva-mate (4), algodão, trigo, mandioca, cana-de-açúcar, batatas, ervilhas, favas, feijōes, abóboras, etc.

No terreno da indústria, sabemos que não sòmente foram muito desenvolvidos os cortumes, a fiaçāo e tecelagem, chegando a ocupar quarenta e até cinqüenta teares (5), mas que os indios se aplicavam também a qualquer sorte de manufaturas. Copiavam os modelos europeus e chegaram a executar os mais complicados aparelhos e máquinas bem como instrumentos de música e relógios. Na Missāo foram fundidos sinos de bronze, com material vindo do Peru.

Na preocupaçăo de atender às necessidades espirituais de seus discípulos, os Padres tiveram sempre presente o grande valor da música: a música atingiu em São Miguel um desenvolvimento que lhe valeu notoriedade na Europa.

(2) Segundo uma estatística de 1732 , os Sete Povos possuiam em conjunto 65.000 vacas, 7.000 cavalos e 15.000 ovelhas.

(3) Pôrto, Aurélio, História das Missōes Orientais do Uruguay, p. 222.

(4) Gay, Joāo Pedro, Cónego, História da República Jesuítica do Paraguai, p. 323: -A preparacão da erva se fazla com esmêro, de tal modo que tóda a que procedia de Míssóes, tinha preferencia nos mercados de Buenos-Aires. Houve época em que se subministravam anualmente até quarenta mil arrobas a este mercado...D

(5) Sepp, Antonio, Padre S. J., Viagens as Missóes Jesuiticas, Introduçá, p. 50 . 


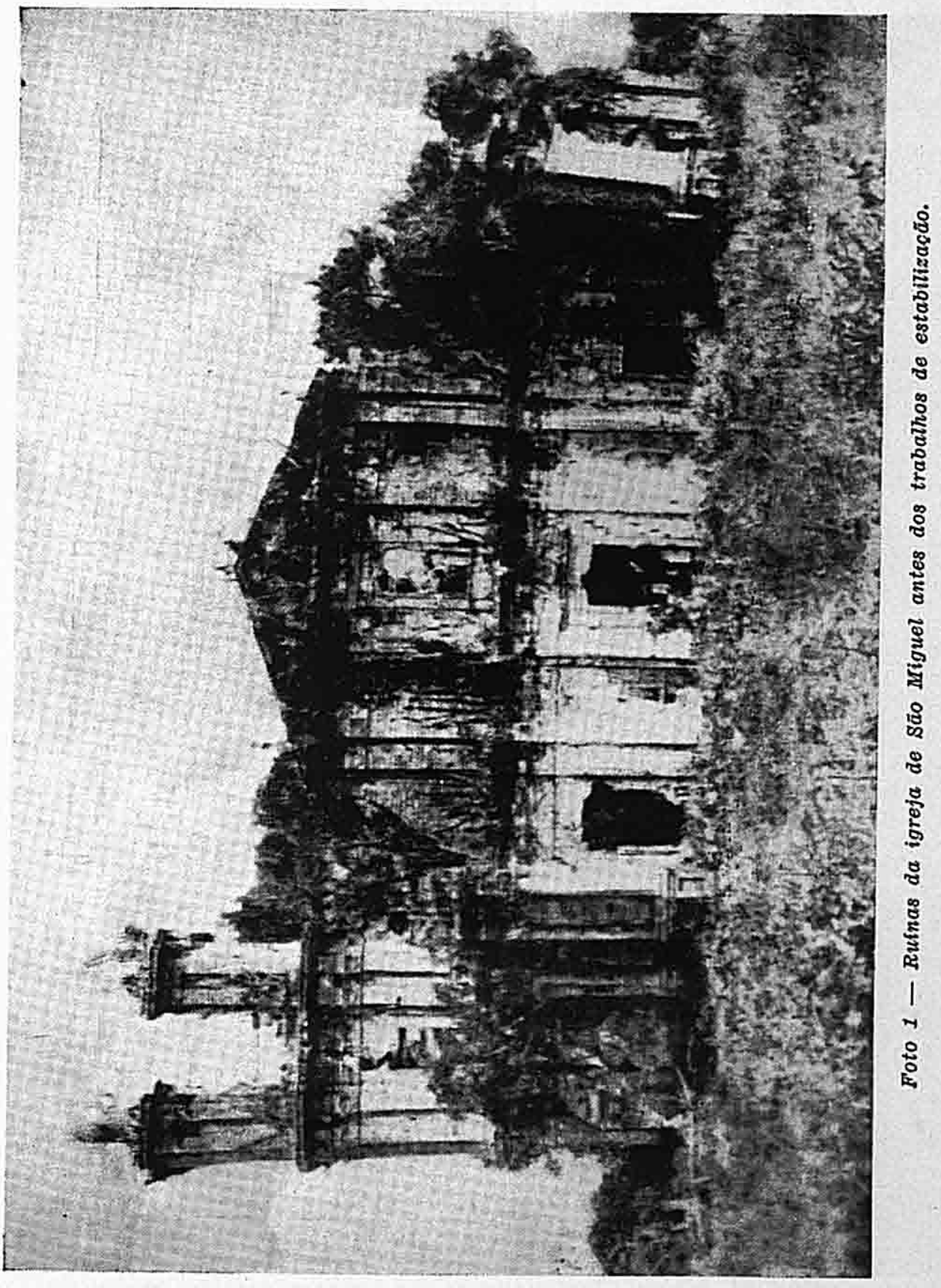



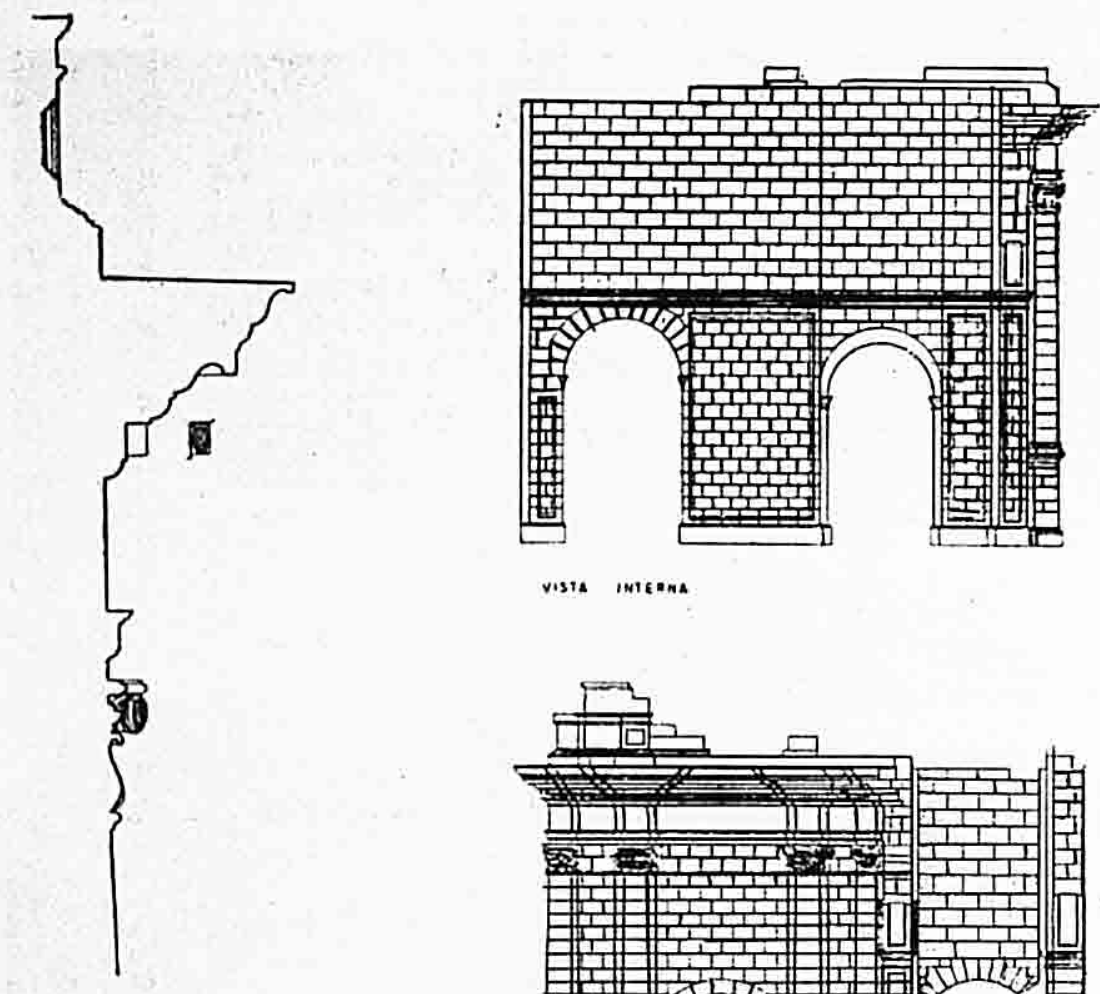

vista INTEAMA

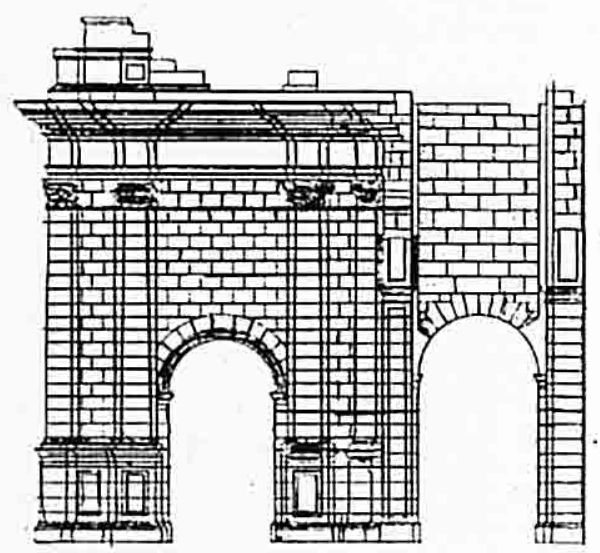

VISIE ExICANA<smiles>C1=CC=C2C=CC=CC=C2C=C1</smiles>
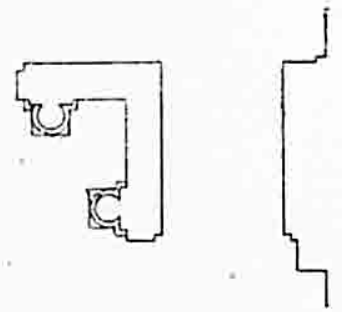

planta e thevacoes

OCTALAE

Foto 2 - Pórtico da igreja de São Miguel. Levantamento. 


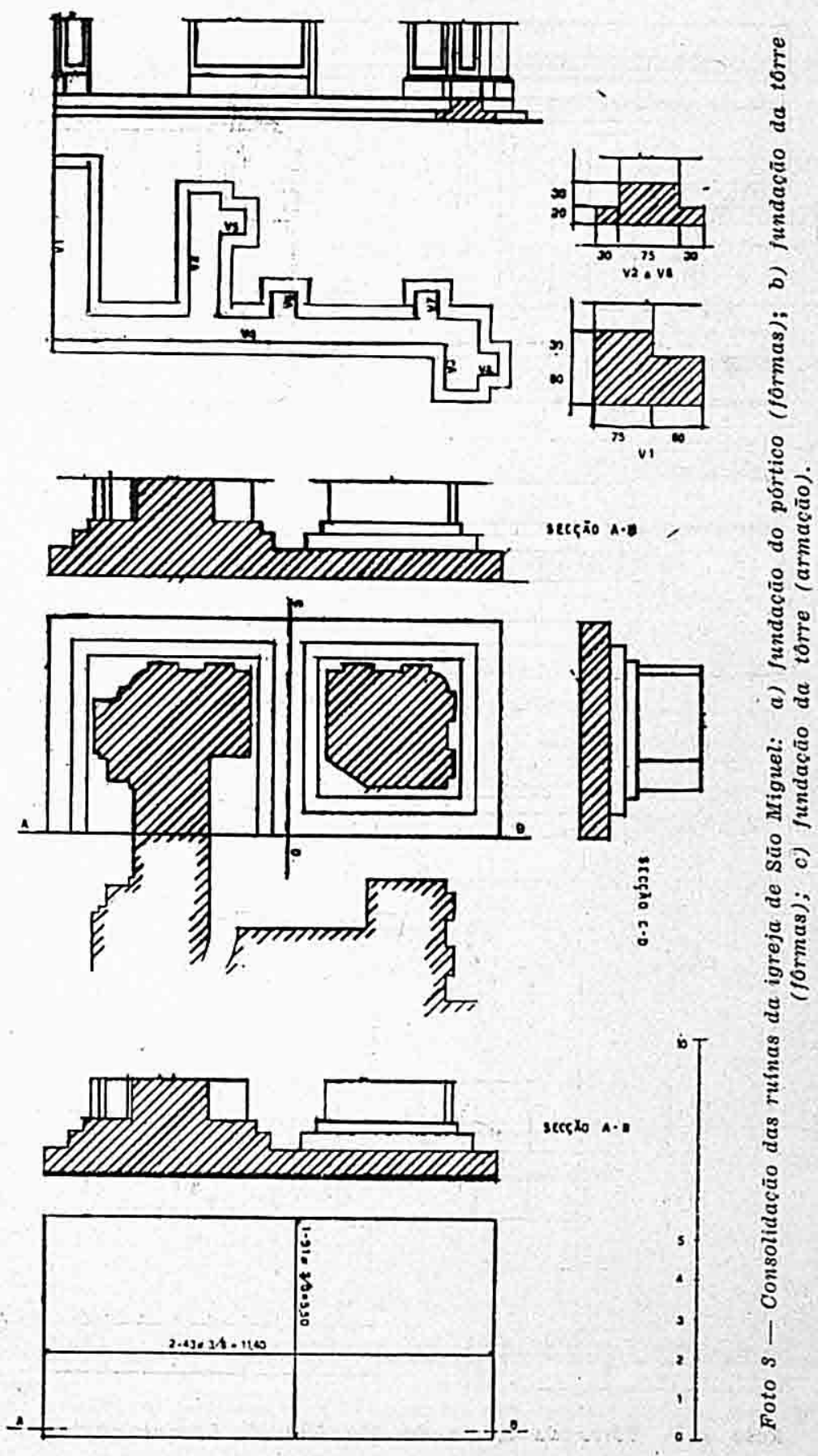



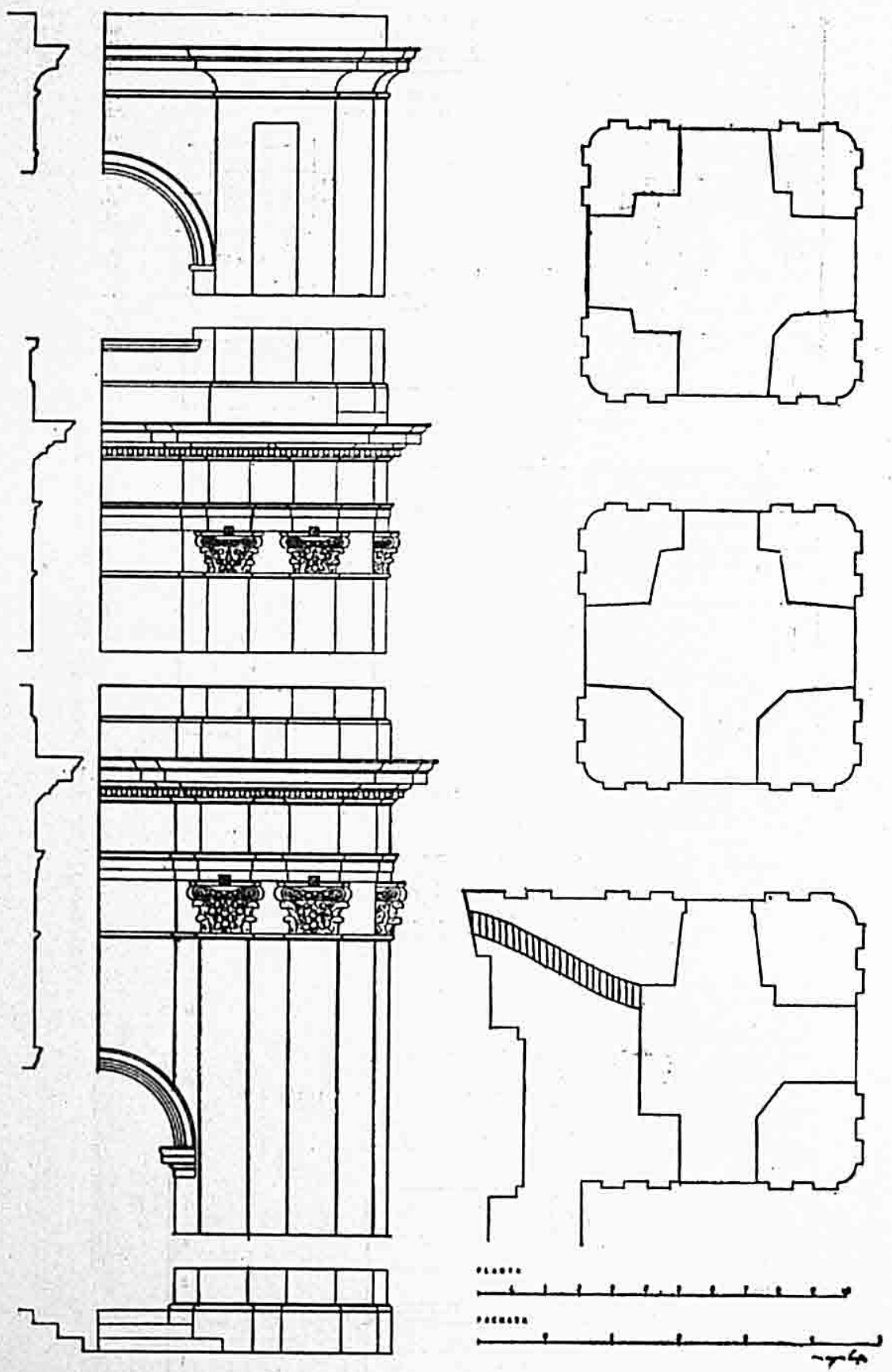
Foto 4 - Tórre da igreja de São Miguel. Levantamento. 


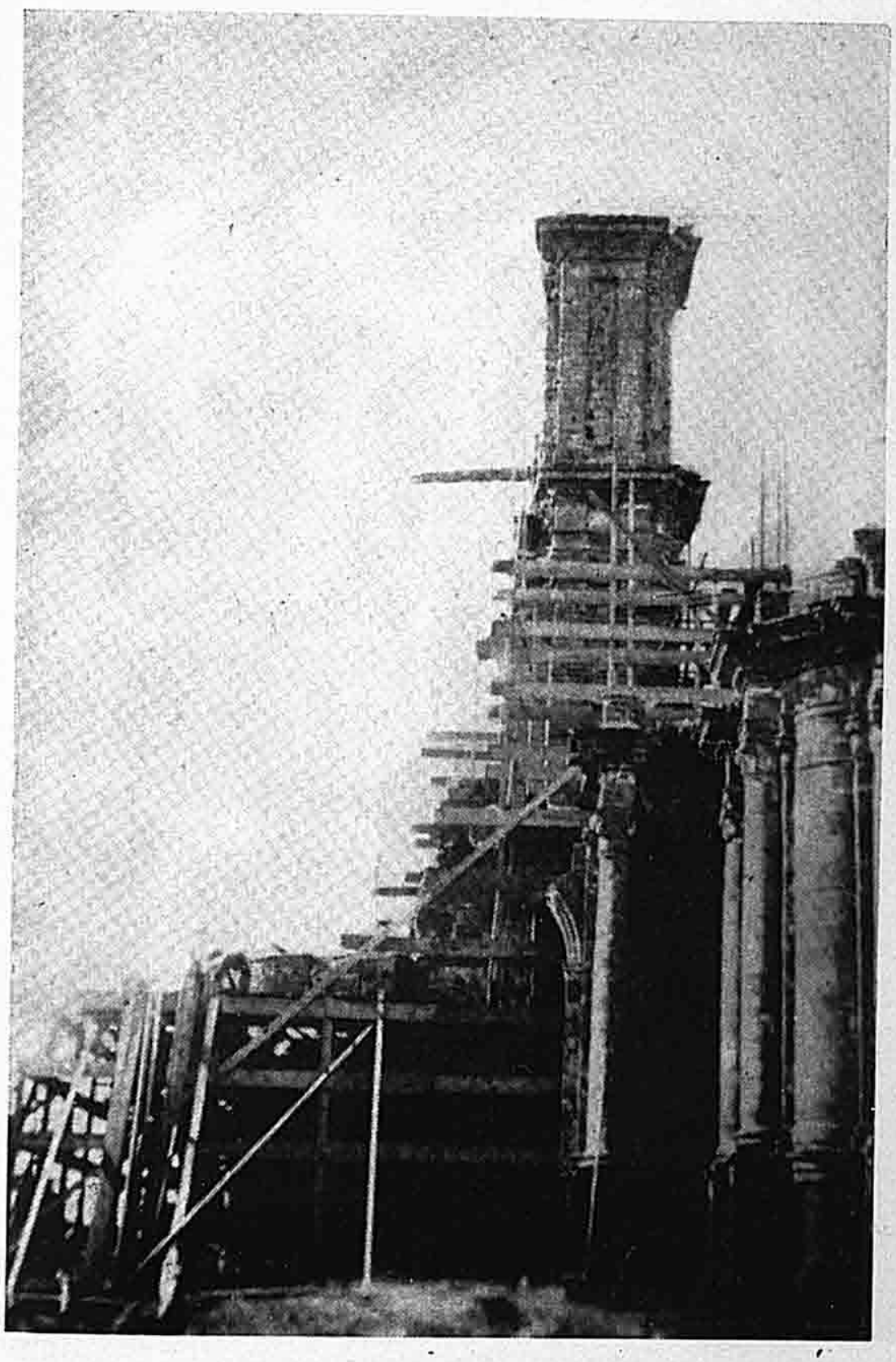

Foto 5 - Tôrre da igreja após o desmonte dos cunhais do lado esquerdo que se haviam desaprumado. 


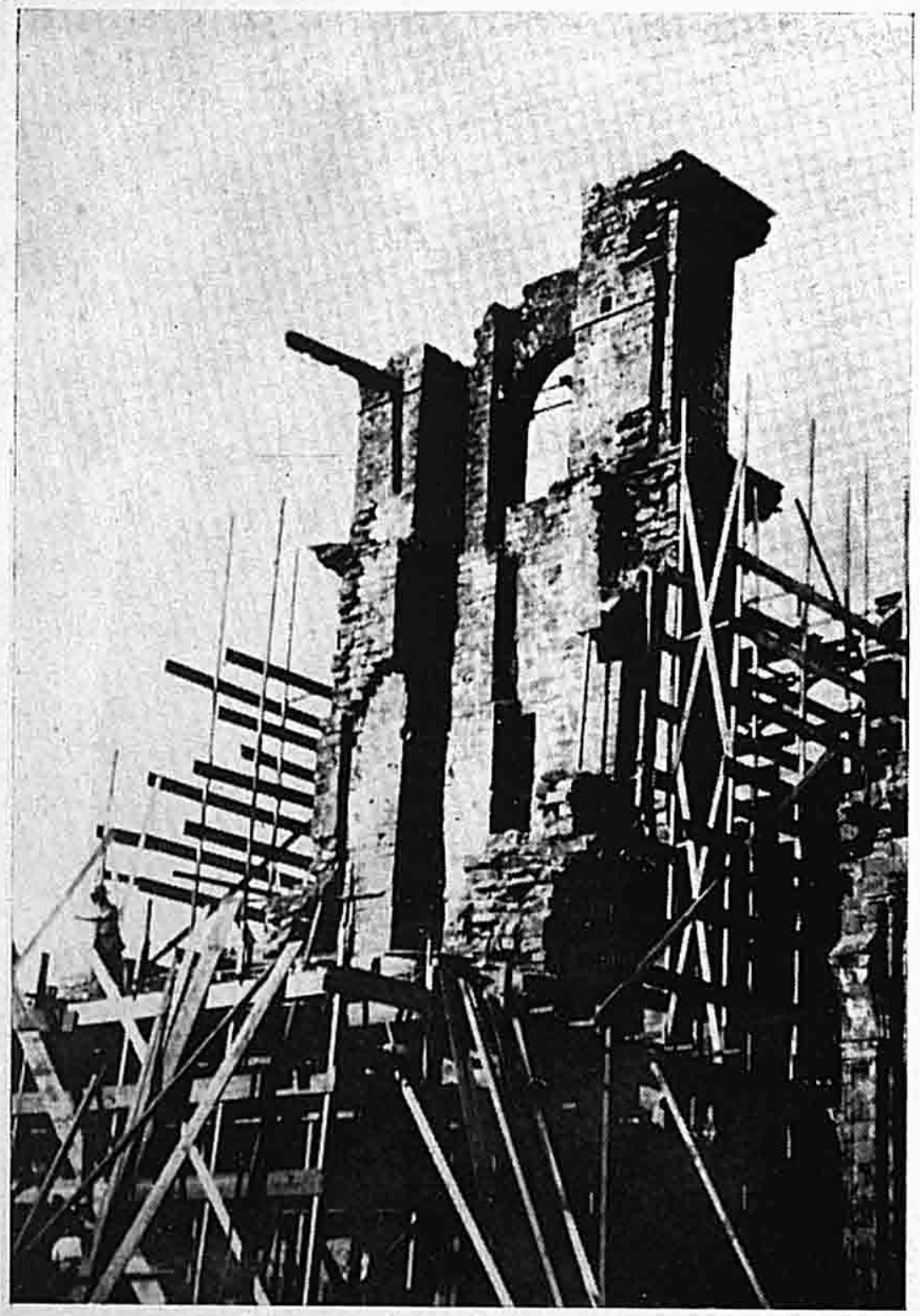

Foto 6 - Vide legenda foto 5 . 


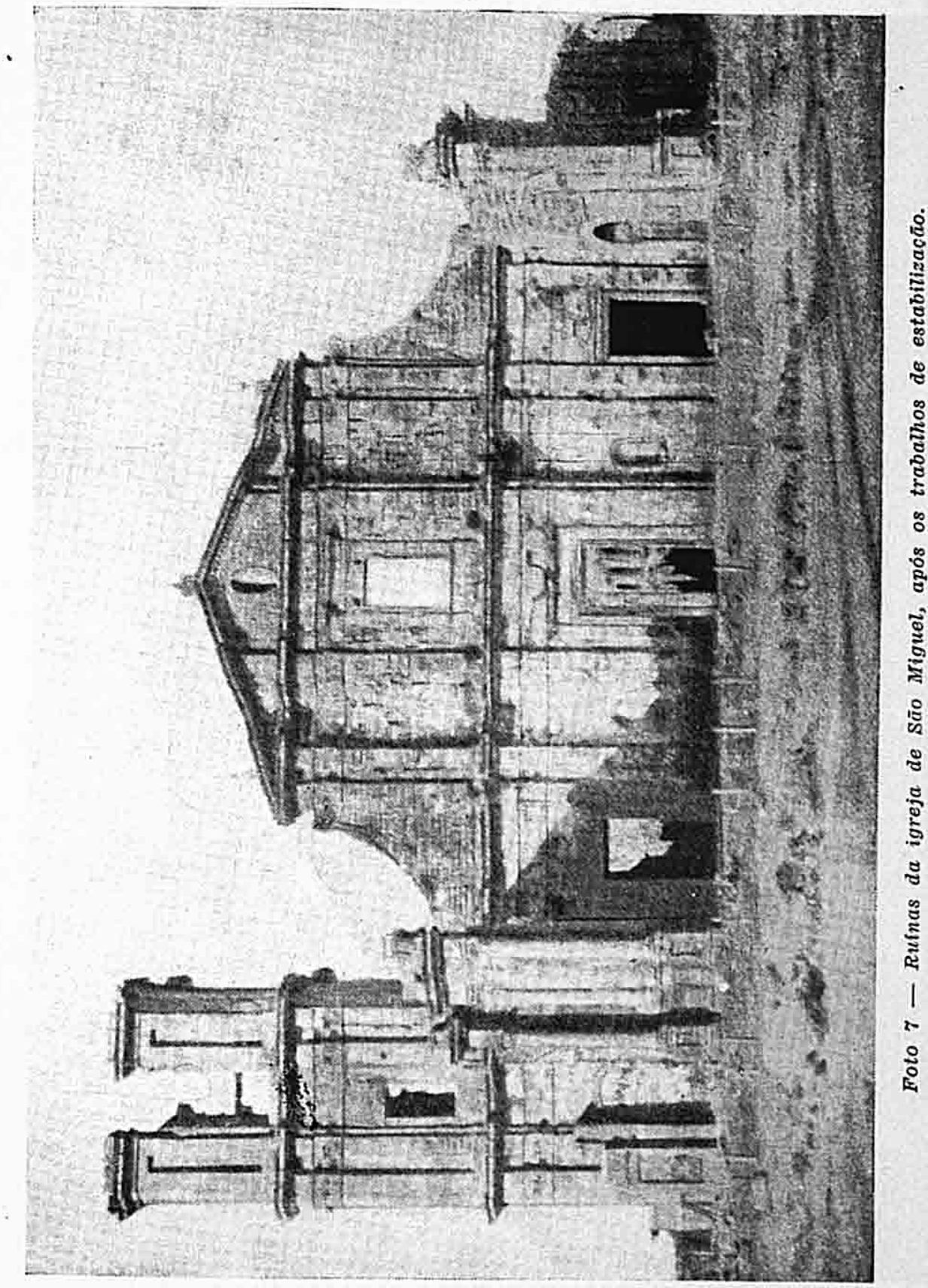




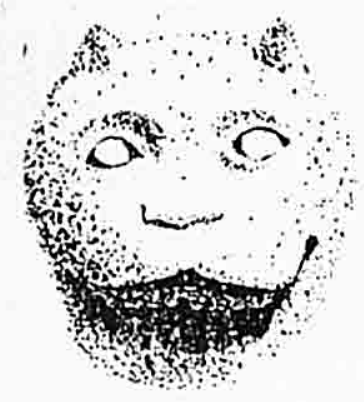

Foto 8 - Exemplo da gárgula cncontrada em três ângulos.

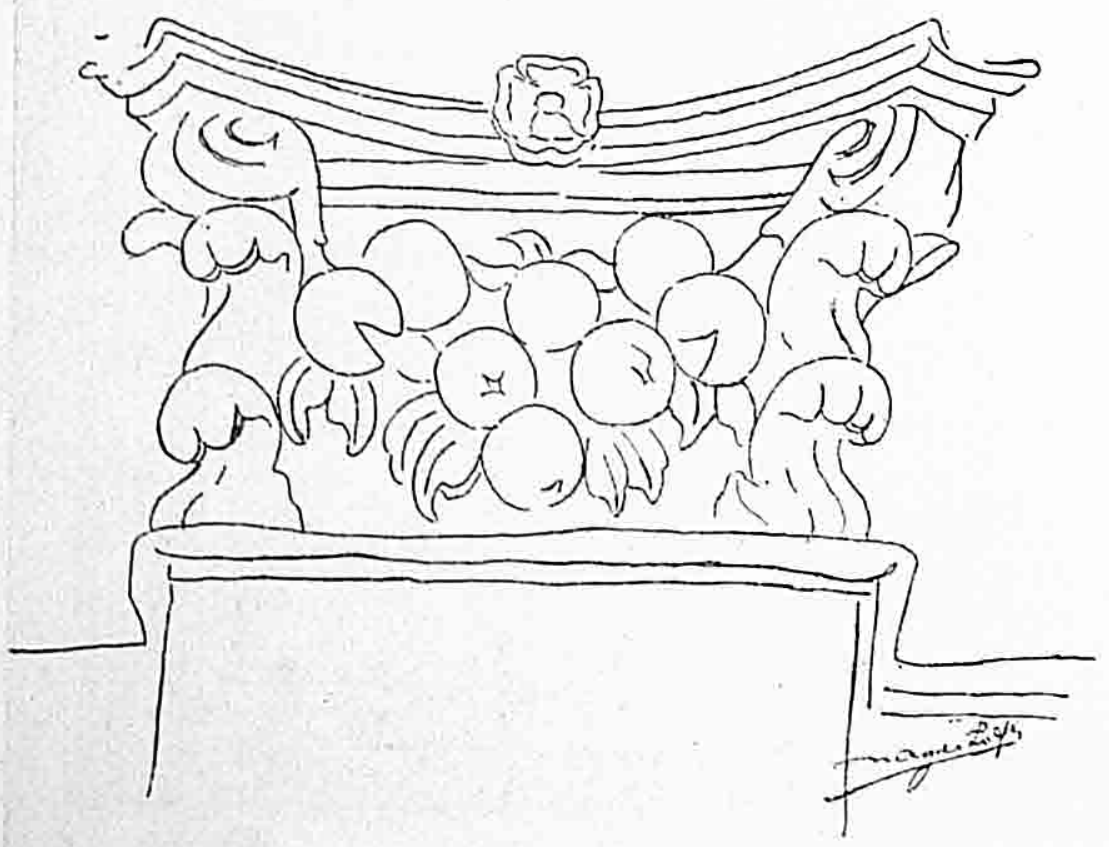

Foto 9 - Capitel, ornado de representação de fôlhas, flôres $e$ frutas de romã, dispostos como se fôssem de acanto. 


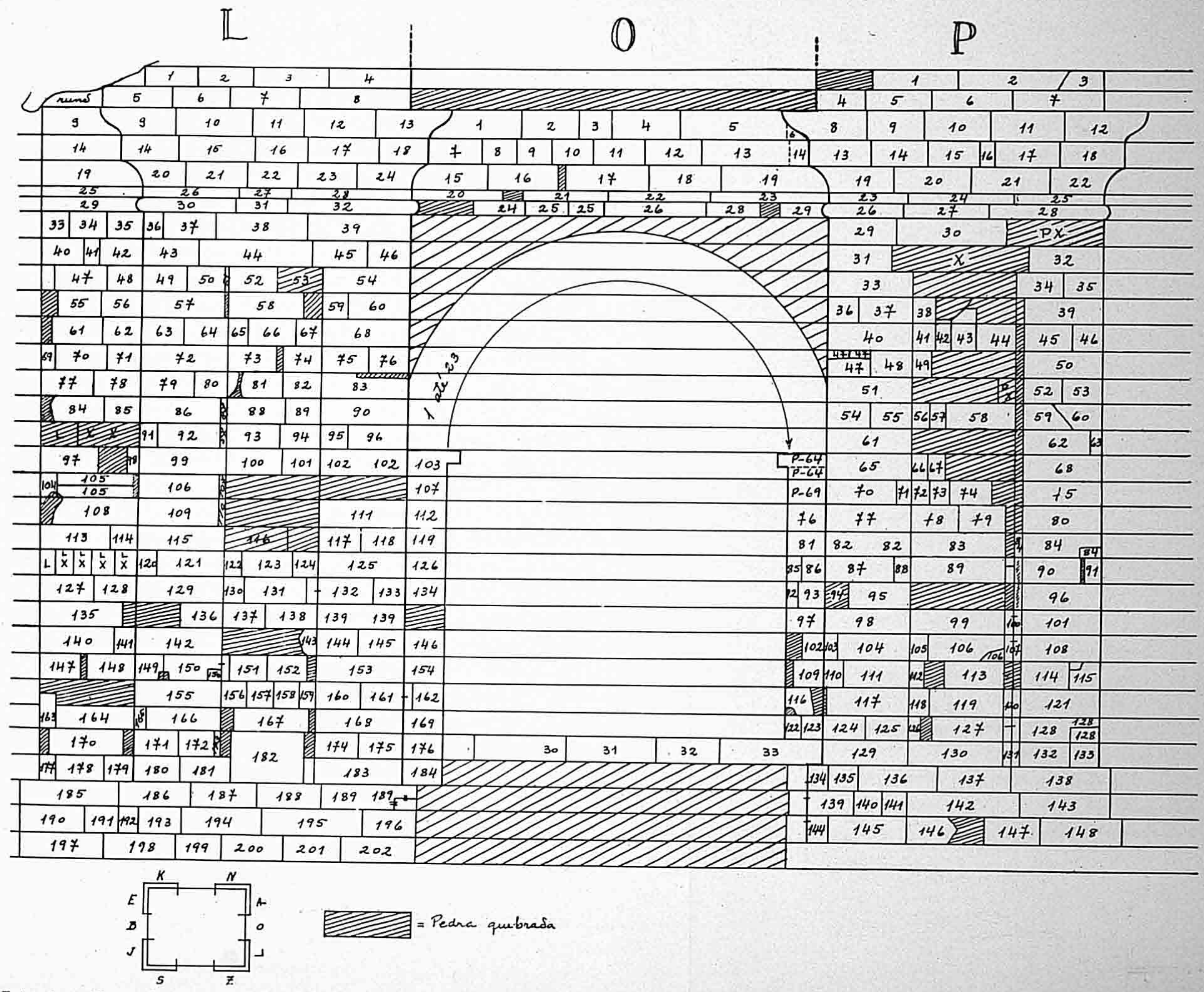

Foto 10 - Planta da tôrre com disposição e numeração das pedras, depois da sua consolidação. 


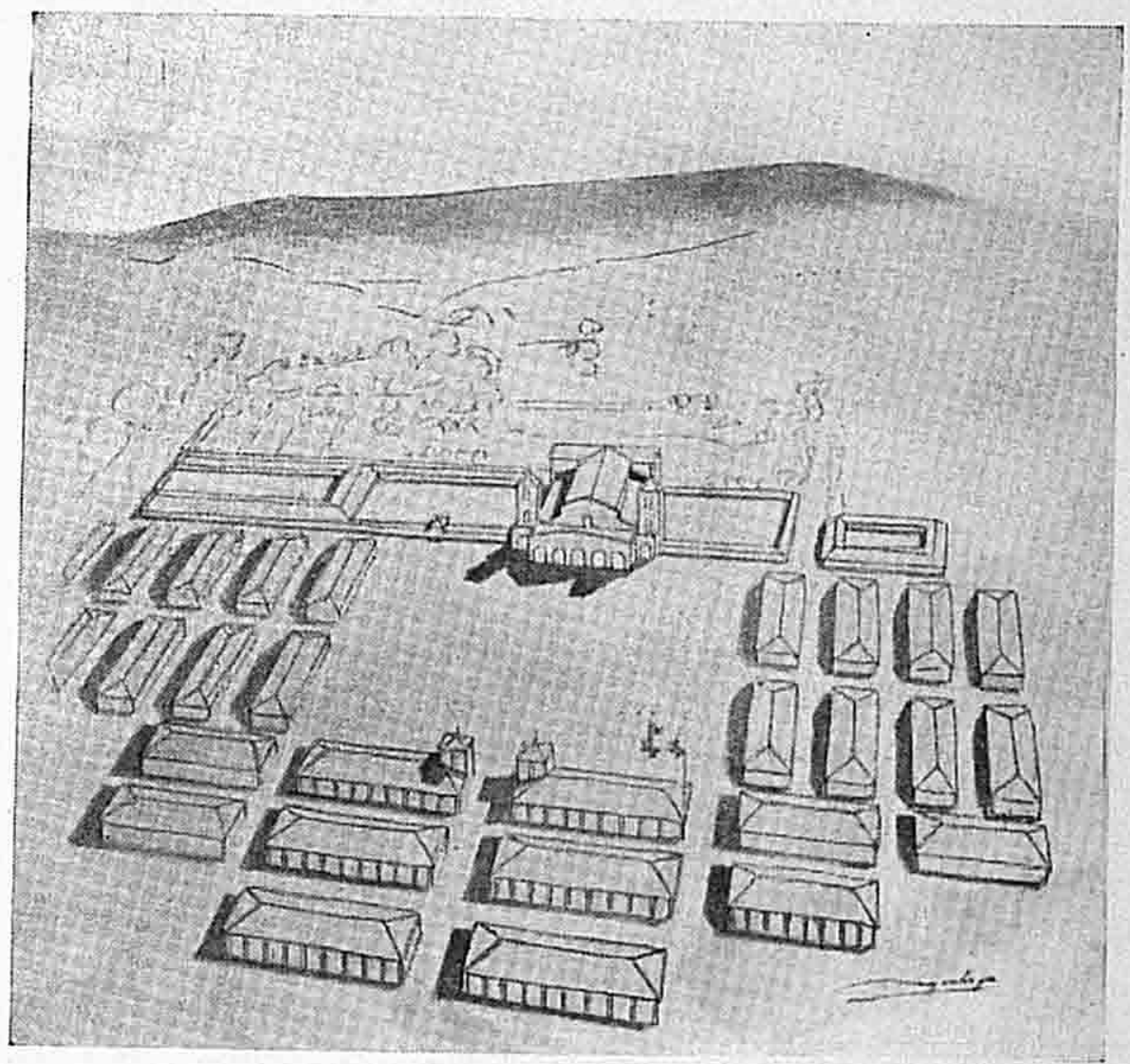

Foto 11 - Reconstituicão do Povo de Sũo Miguel. Perspectiva. 


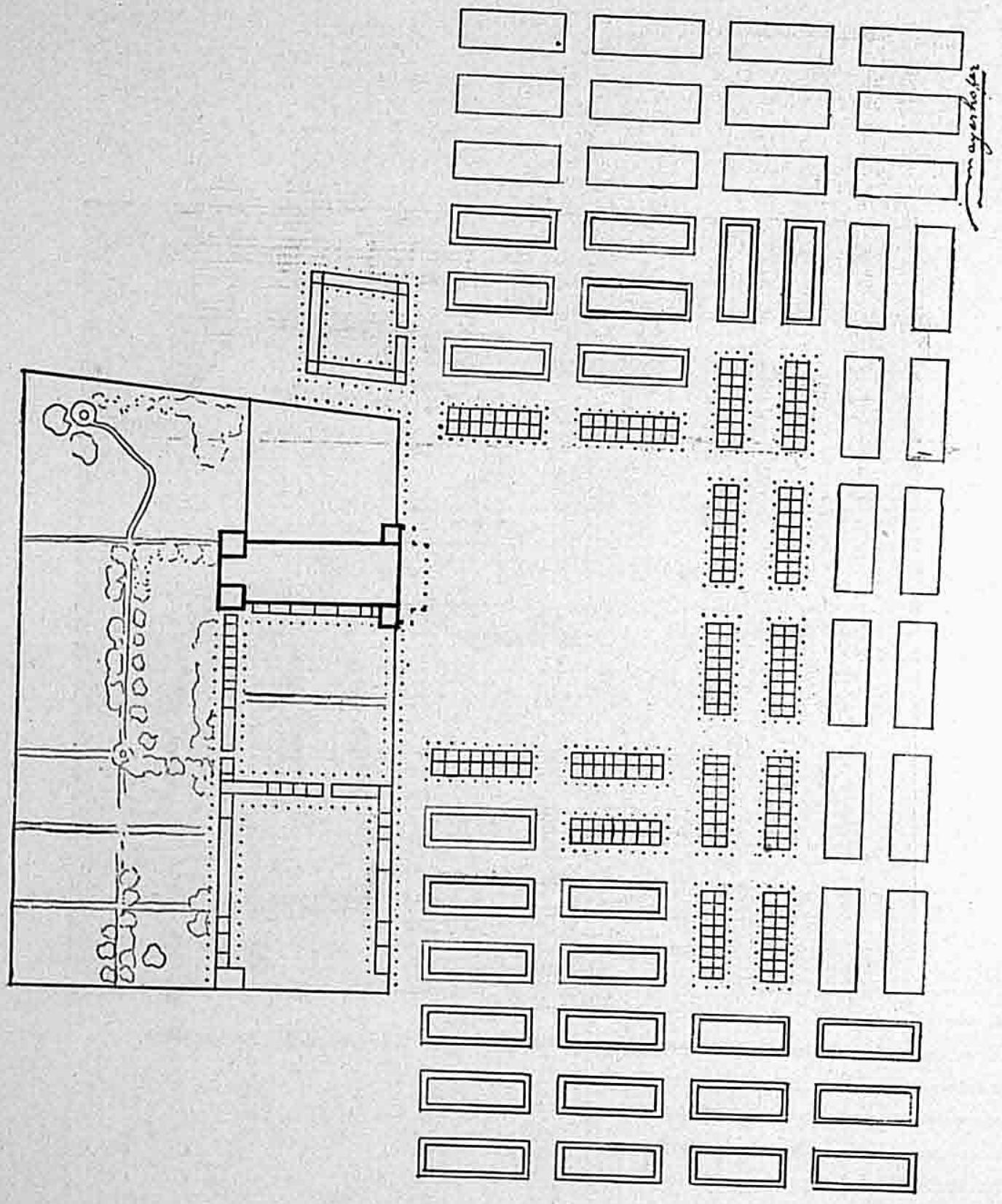

Foto 12 - Reconstituicão do Povo de São Miguel, planta de conjunto. 


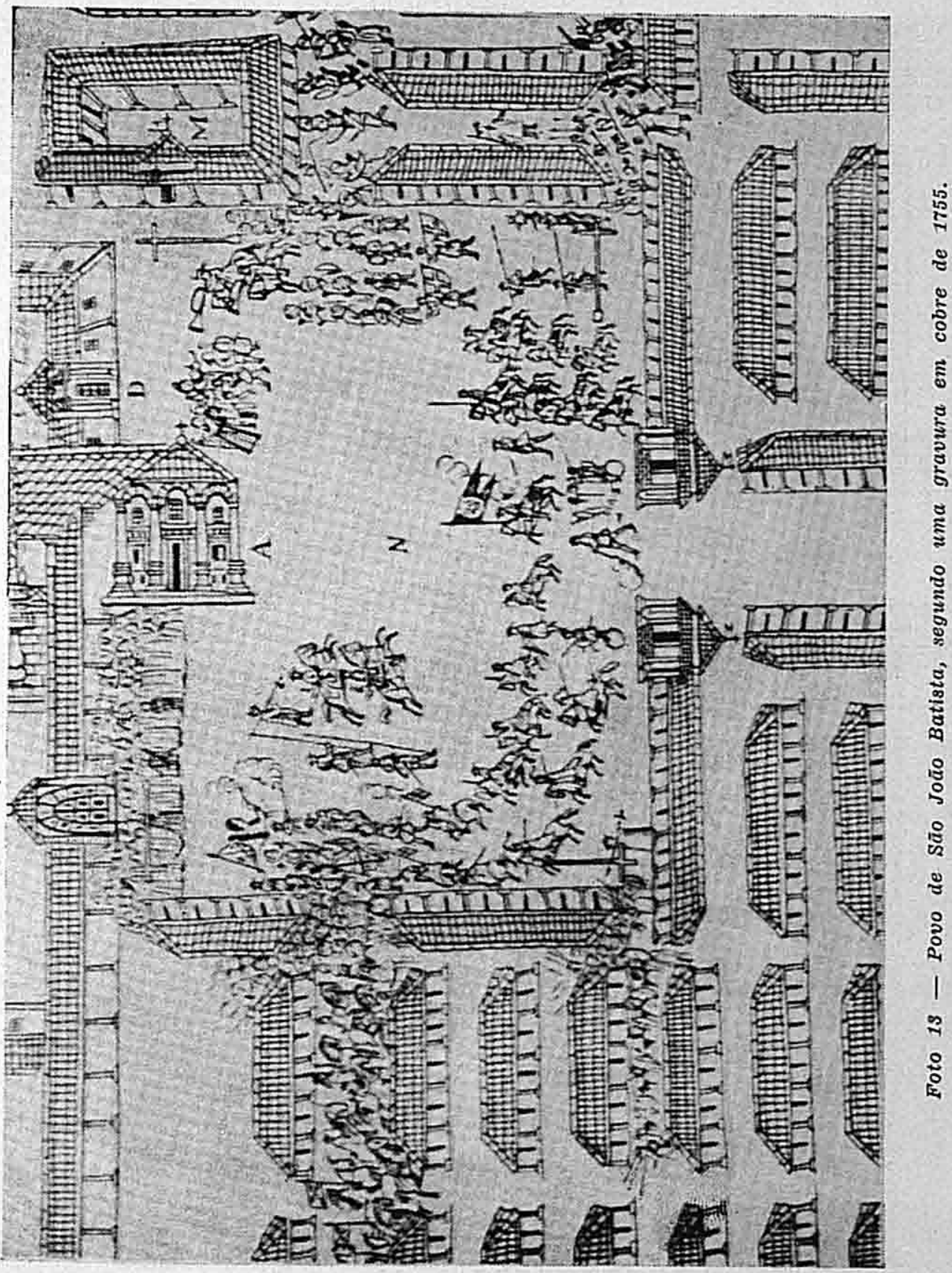




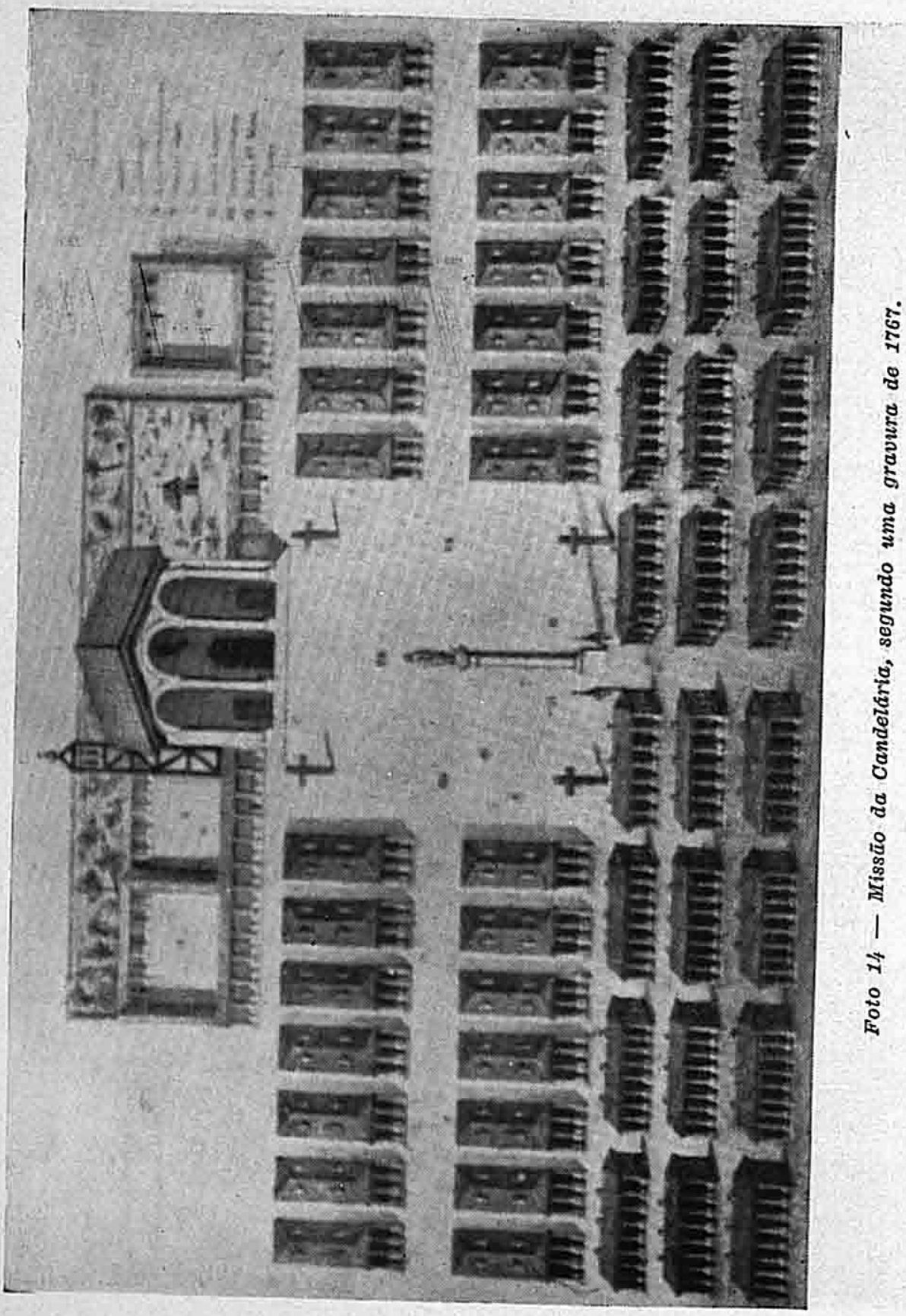



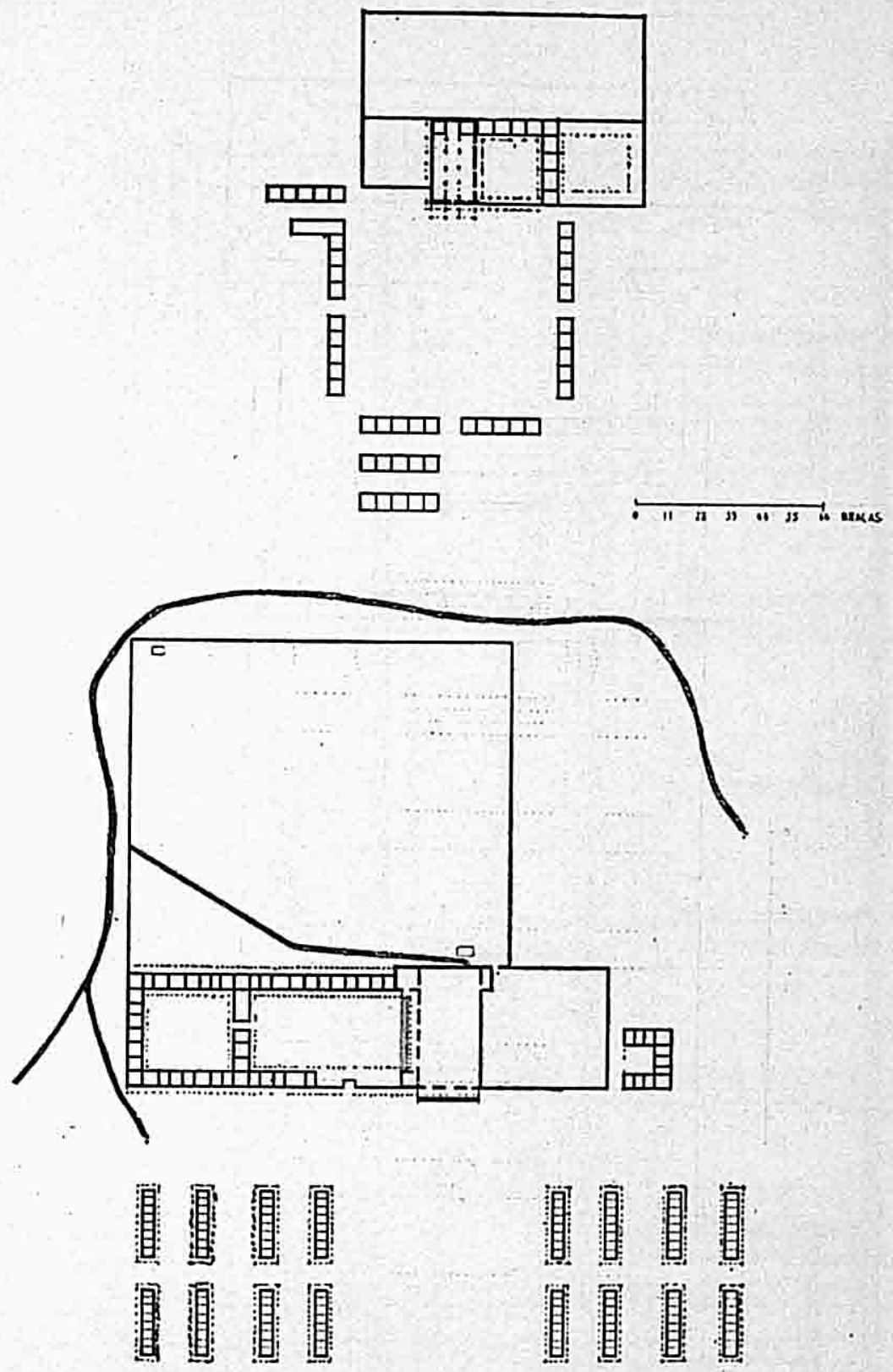

:

(1)

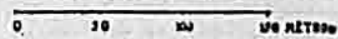

Fotos $15 a$ e $15 b$ - Plantas das Missões de são Borja, segundo a reconstituicāo de Manuel de Almeida Coelho, em 1816; San Ignatio Mini, segundo a reconstituiçäo de Juan Queirol. 


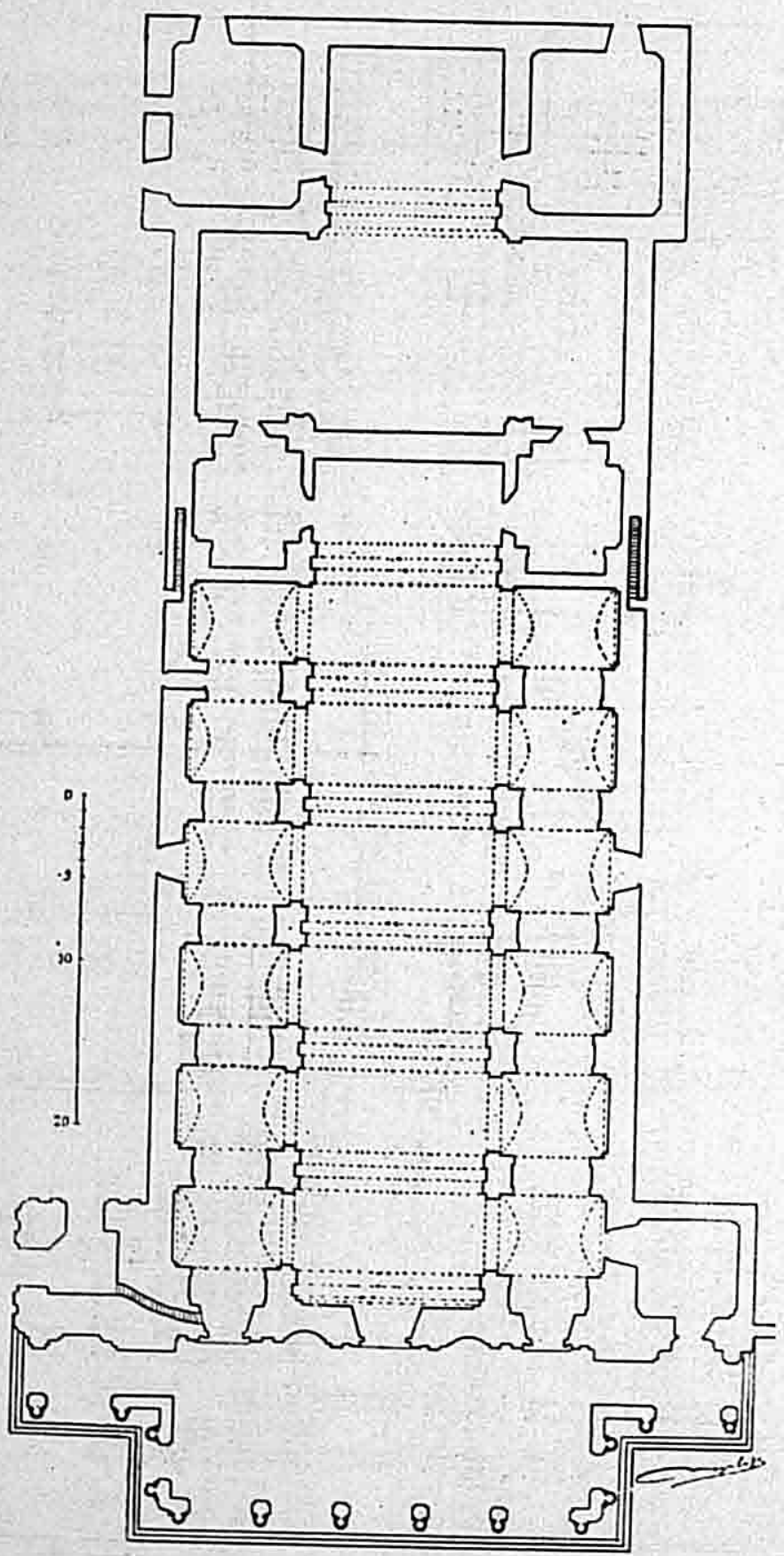

Foto 16 - Reconstituicão da igreja de São Miguel baseada nos elementos subsistentes. Planta. 


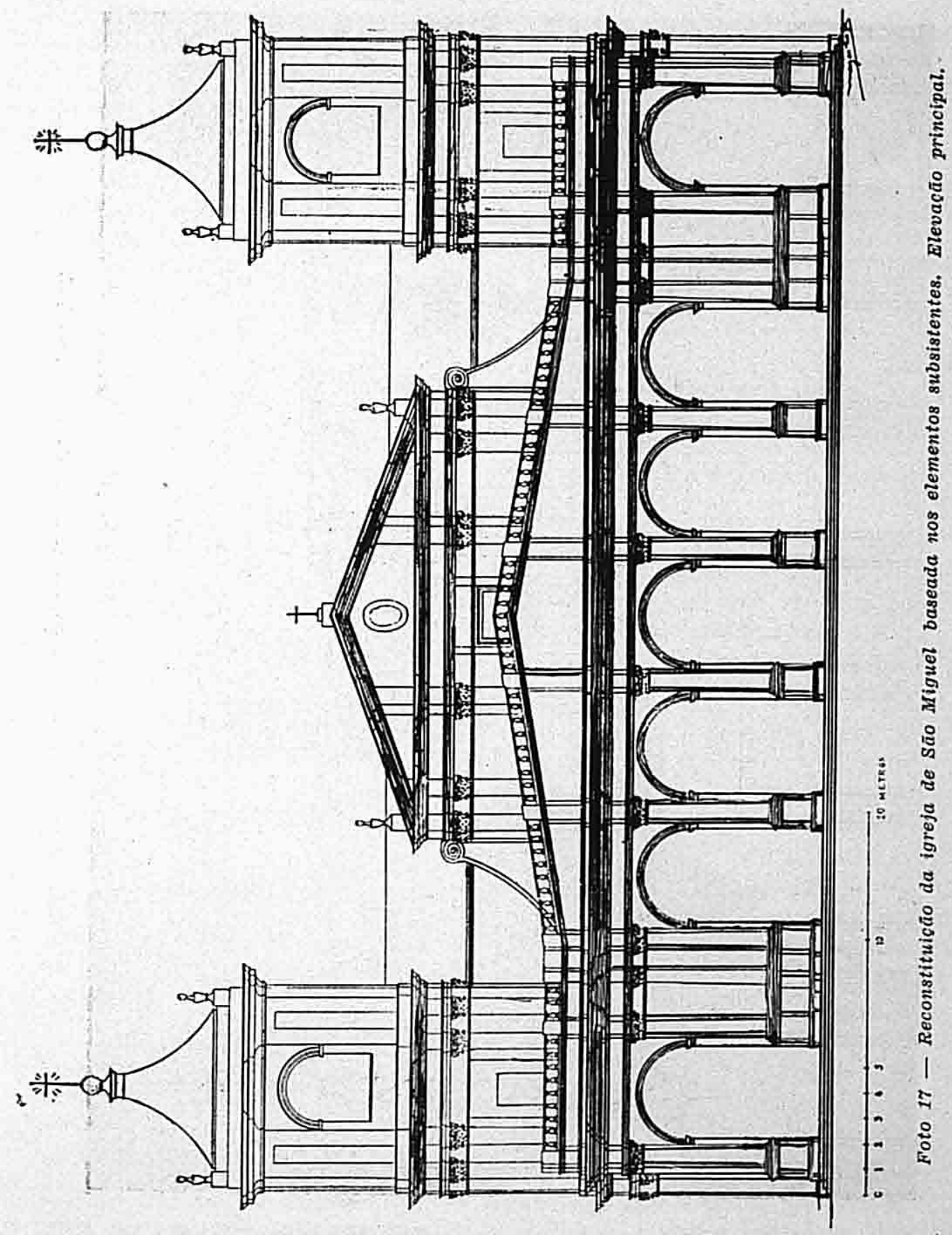




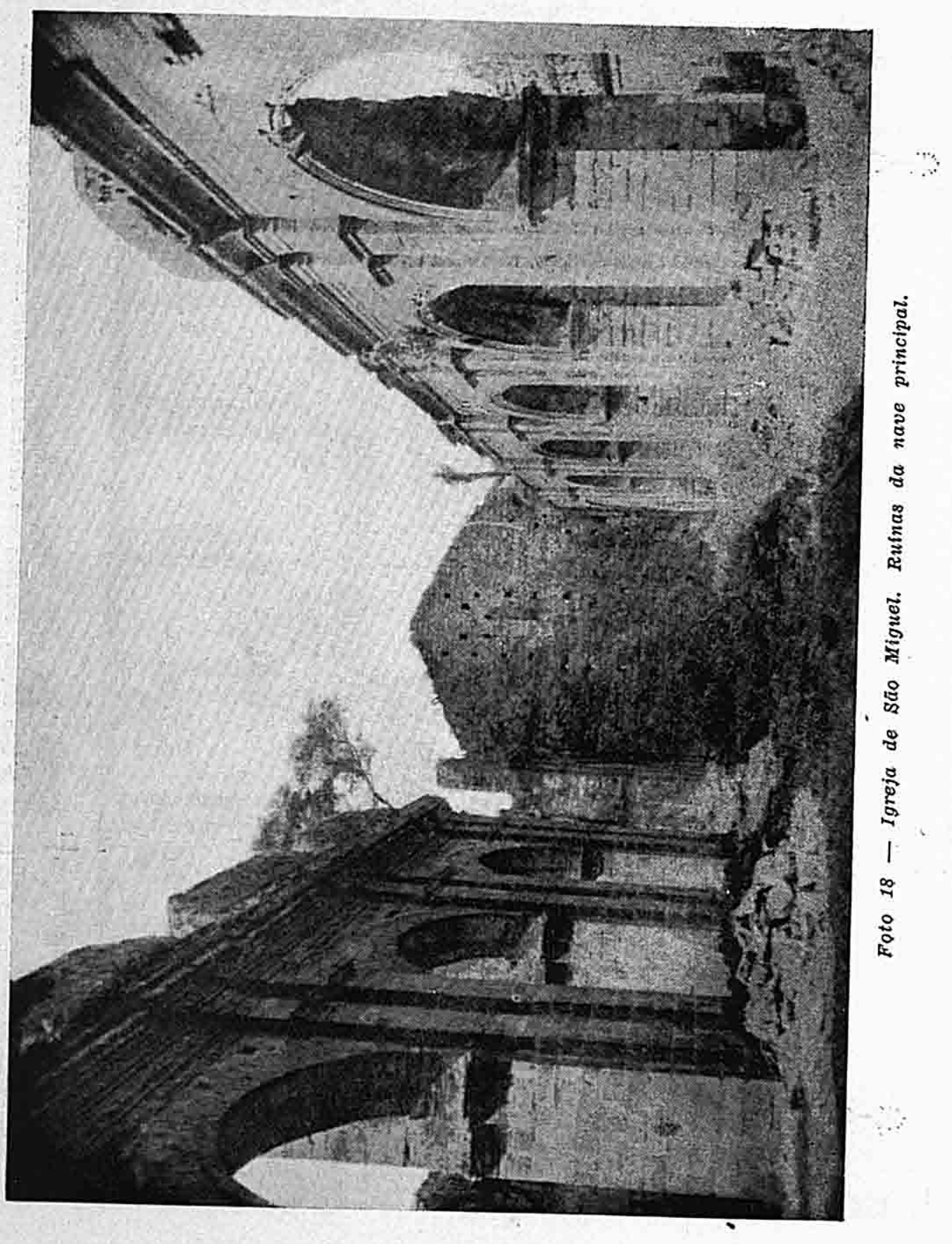


Nem foram esquecidas as artes plásticas, cujo interêsse foi estimulado e mantido entre os indios pelos Padres da Missão.

Bem haja tal interêsse que nos permite, séculos depois, pelos remanescentes dessas atividades artísticas, vislumbrar a Arquitetura e a Escultura missioneiras.

E fácil compreender-se como, fruindo das condiçōes amenas de uma vida útil e abrigada, os indios fôssem aos poucos perdendo suas caracteristicas agrestes e se adaptando à vida social das Missōes.

\section{c) DECADENCIA}

Na vida arcádica que levavam, longe estavam os jesuitas e seus protegidos de saber que nas chancelarias de Portugal e Espanha um tratado de limites estava sendo concluído, que viria ferir profundamente a bela realizaçāo das Missōes e marcar o início de seu desenraizamento e de sua morte.

O Tratado de 1750 , permutando a Colônia do Sacramento pelos Sete Povos e estipulando que os respectivos habitantes deviam transpor o rio com todos os bens móveis, ocasionou a revolta profunda que resultou na chamada guerra das Reduçóes, onde se viram padres jesuitas, aliados aos seus indios, lutarem contra os cavaleiros espanhóis e portuguêses para não abandonarem a Missão.

Com a entrada dos exércitos aliados em São Miguel, os indios vencidos, num gesto de desespêro, lançaram fogo à maior parte das casas e ao templo, o qual felizmente foi salvo das chamas. Seguiu-se o saque da aldeia abandonada, por outros indios que nela penetraram e levaram até os sinos.

E verdade que, em 1762, anulado o tratado de limites, houve ainda um surto de vida nas Missōes; porém o abalo jâ produzira efeito, e quando, em 1768 , se ultimou a campanha movida contra os jesuitas com a sua expulsäo da América espanhola, a Missão de São Miguel enveredou pela senda inexorável da decadência.

De fato, bem diferentes passaram a ser as condições de vida dos indios sob a administração colonial espanhola. Abandonados os princípios cristãos seguidos pelos jesuitas, os índios se viram despojados e maltratados, e, como reação natural, passaram a desertar em bandos, vindo trabalhar para as estâncias dos brasileiros e portuguêses.

Ao fracasso do Tratado de 1750 seguiram-se novas pretensōes territoriais dos espanhóis, acompanhadas de lutas que os tratados posteriores nāo conseguiram aplacar. 
O descontentamento dos indios com os administradores espanhóis muito ajudou aos pioneiros da penetração riograndense.

O ano de 1801 assinala um episódio marcante da nossa História.

Os riograndenses José Borges do Canto e Manoel dos Santos Pedroso, à frente de quarenta homens, atacaram as Missōes e derrotaram o exército espanhol de ocupaçăo, constante de 2.000 homens, conquistando definitivamente os territórios da margem esquerda do Uruguai para o patrimônio nacional.

No que toca aos Povos Missioneiros, objeto de nosso estudo, êstes, já decadentes devido aos fatôres expostos, depois de tantas lutas, foram desintegrando até o seu completo desaparecimento.

R E C O N S T I T I C A O

\section{I - Do Povo}

Com as obras de estabilização descritas no capitulo anterior, ficaram preservados da destruição os elementos arquitetônicos de maior valor, existentes nas Missōes.

As ruinas da igreja de São Miguel, os muros meio tombados e os alicerces que ainda existem das construçōes que compunham o Colégio dos jesuítas não bastam, porém, para nos representar o antigo Povo, com o traçado regular, característico de seu conjunto monumental.

Auxiliados, entretanto, pelos escritos do tempo, pelas descriçōes dos historiadores e dos viajantes que em diferentes oportunidades percorreram a regiāo, assim como pelos autores modernos que comentaram os textos dos jesuitas, referentes ao assunto, ficamos habilitados a deter-nos com o necessário interêsse no objeto do nosso trabalho: A reconstituição do Povo de São Miguel na época de seu maior florescimento.

Partimos da premissa de ter sido a Missāo criada em obediência a um plano pré-estabelecido.

Em verdade, a fundação das Missōes pode ser comparada à das antigas colônias dos romanos no norte da Africa: Timgad, Volubilis, Caesarea.

De fato, o espirito barroco veio restabelecer na mentalidade do Ocidente aquela preocupação com os efeitos de conjunto e de impressão geral que se perdera com a destruição do sistema social do mundo antigo. Pode ser dito, em favor do barroco, que foi o primeiro periodo, depois do romano, 
em que se planejaram edificaçōes com intenção estética visando ao proveito coletivo: cidades, ruas, praças.

No caso das Missōes jesuiticas, as dificuldades eram bem maiores, pois os povos indígenas não tinham senão uma organização social rudimentar e possuiam apenas indústrias primárias.

Nem por isso faltou às mais rústicas realizaçōes missioneiras a emoção caracteristica da arte da Contra-Reforma; porque o drama da Salvaçāo, que é a essência do barroco, em nenhuma parte se expandiu melhor que nessas Missóes jesuiticas, onde tudo era criado tendo-se em vista êsse ideal religioso.

O Povo de São Miguel foi construído sôbre uma colina, de modo a facilitar o escoamento da água das chuvas freqüentes.

A Missão devia obedecer ao plano geral estabelecido nas Leyes de Indias, Libro IV, Título Siete: "De la población de las ciudades, villas y pueblos".

O traçado se desenvolveria em tôrno de uma praça quadrangular, medindo aproximadamente $130.00 \mathrm{~m}$ de lado (fotos $11 \mathrm{e} \mathrm{12).}$

O lado que olhava o nor'ce era limitado por muros e construçōes do Colégio, pela igreja e pelo cemitério; os outros três lados pelas casas dos indigenas, dispostas em anfiteatro e separadas por nove ruas que partiam da praça.

Com efeito, encontramos disposição semelhante noutras Missōes hoje desaparecidas, mas cujas plantas antigas nos foram conservadas.

a) Na Missão de São João Batista, fundada para dividir o numeroso Povo de São Miguel e que aparece na curiosa gravura em cobre de 1755 (foto 13);

b) No Povo da Candelária, em Misiones, segundo uma gravura de 1767 (foto 14);

c) Na Missão de São Borja (que se desenvolveu e é hoje ponto terminal da via férrea, linha Montevidéu-Quaraim-São Borja), segundo a planta levantada por Manoel Joaquim de Almeida Coelho, em 1816 (foto 15a);

d) No Povo de San Ignacio Mini, em Misiones, segundo uma reconstituição feita em 1899 pelo agrimensor Juan Queirol (foto 15b). do tipo.

Os autores antigos confirmam essas plantas e mostram a recorrência

Dominando o conjunto, elevava-se a magnifica igreja tôda de pedra e precedida de rico pórtico. 
A sua direita ficavam as casas do Colégio, que se dispunham em volta de dois grandes pátios. Essas construçōes eram dotadas de duplas varandas, exterior e interior, construídas com pilares de pedra lavrada. Do lado esquerdo da igreja, o cemitério. Segundo uma referência do Cônego João Pedro Gay, numa descriçāo das Missōes, o cemitério, cercado por paredes altas, seria plantado de ciprestes, palmeiras e laranjeiras, formando ruas por onde circulavam as procissões, e dividindo terrenos para as sepulturas, reservadas a despojos de inocentes e de membros das Irmandades. Fazia-se na igreja, junto ao altar-mor o sepultamento dos jesuítas. Ao meio do cemitério, de certo, uma grande cruz se levantaria, como nas outras Missōes. Pelo lado dos fundos, ao longo do Colégio, da igreja e do cemitério, devia ficar a quinta dos Padres, murada de pedra e barro, com jardim, pomar e horta (6).

Seriam do tipo espanhol as casas dos indigenas, construidas em blocos cobertos por telhados de quatro águas, com grandes varandas, que as cercavam de todos os lados, de forma que se podia percorrer o Povo ao abrigo do sol e da chuva.

Ainda encontramos alicerces e bases de muitos pilares dessas varandas. E foram êsses alinhamentos de bases que nos permitiram calcular as dimensōes da praça e a disposiçăo dos blocos de habitação que a circundavam.

No ano de 1630 já o Povo de São Miguel contava 100 dêsses blocos cobertos de telhas. Cada bloco era provàvelmente dividido em quatorze compartimentos, alojando-se ai uma familia inteira.

A Missão chegou a ter cêrca de 100 blocos, correspondendo às 1214 familias, e ao total de 4859 almas, população a que atingia em 1732, depois de ter sido desmembrada para a fundação do Povo de São João Batista.

O edificio do Cabido ocupava provàvelmente um dos blocos situados no lado da praça oposto à igreja. Atrás dêsses blocos deviam ficar as casernas do regimento guarani; era essa sua localização em 1816, conforme se vê na planta do Povo de São Borja, segundo o levantamento feito por Manuel Joaquim de Almeida Coelho.

Os pórticos ou galerias ao longo das ruas, que constituiam o luxo da Arquitetura na Antiguidade e tinham sido novamente postos em favor pelo Renascimento (Loggia dei Lanzi, em Florença), foram aqui prodigalizados a um ponto que contrasta com o primitivismo das habitaçōes, onde uma familia inteira apenas dispunha de um único compartimento para tôdas as necessidades de moradia.

(6) De Moussy, Memória Histórica sobre la decadencia $y$ ruina de las Misiones Jesuiticas en el seno del Plata, p. 18: eFi unico lujo que se permitian los padres era el de una hermoza huerta blen plantada de naranjos, parras, higueras, durasneros, granaderos, guayaveros, bananos, palmos, etc, etc, e de todos los legumbres de Europas. 
Pelos alinhamentos de bases existentes, vê-se que, além de circundarem as habitaçōes dos indigenas, êsses alpendrados se estendiam pela frente da igreja, do Colégio e do cemitério; em volta dos pátios intemos do Colégio; externa e internamente ao longo do muro de frente do Colégio e por trás dêste, dando para a quinta dos jesuitas; externa e internamente no edificio do hospital.

Não encontramos nenhum indicio de como o Povo de Sāo Miguel se abastecia de água potável. Quando as Missões se situavam à margem de um rio, a água era retirada dêste à medida que deveria ser utilizada. Sabemos que assim se procedia em 1691, em Japeiú, entāo a Missāo mais importante de tôdas.

Na Missão de San Ignacio Mini, em Córdoba, a água era trazida por meio de canalização subterrânea até um reservatório construído na quinta dos Padres.

O padre Antônio Sepp mostra-nos a atenção que dispensou ao abastecimento d’água, na escolha do sítio para a fundação do Povo de São João Batista, em 1697:

"Coloquei-vos numa encosta aprazivel, sobranceira e lavada de todos os ventos. Ao sopé, como num segundo paraíso, vos abriu o Boníssimo Deus quatro fontes muitíssimo salutares, tanto para os homens como para o gado. Delas emana, sem cessar, limpidissima água, e, podeis crer, não secarão mesmo na canicula de Janeiro, pois têem as suas nascentes entre perpétuas sombras de árvores frondosas, e as mesmas pedras duríssimas gotejam num perene lacrimejar, que pouco a pouco escorre em arroios e rios.

Em São Miguel acreditamos que para o abastecimento do Povo se tivesse recorrido à água de sub-solo, pois foi o modo por que conseguimos água para o Museu das Missões, por nós construido em 1939, para o Serviço do Patrimônio Histórico e Artístico Nacional.

A água seria puxada dos poços por uma nora.

Uma descrição do padre Sepp dá-nos idéia da iluminaçāo das praças das Missões, em dias de festa:

"Como ficasse noite e como não houvesse nem cera nem óleo para a iluminação, tomaram de chifres de bois, que são aqui extremamente grandes e compridos, encheram-nos de graxa e sebo, acenderam-nos e os levantaram para cima. Por meio dêsses chifres ardentes transformou-se a noite escura em dia claro, como que iluminada por tochas, e os dançarinos e cavaleiros eram iluminados e tornados visiveis." 


\section{II - DA IGREJA}

Se o traçado das aldeias e os programas das construçōes deviam obedecer ao padrāo determinado nas "Leyes de Indias", a plástica geral e de detalhe variava, certamente, conforme a cultura do chefe do Povo ou dos artistas que executavam os trabalhos. E como tais artistas haviam deixado de há muito o país natal, suas concepçōes acompanhavam o movimento de arte da Europa, mas com o atrazo de uma geração.

Assim é que vemos o padre Antônio Sepp evocar, nas construçōes do Povo de São João Batista, as imagens queridas de sua cidadezinha no Tirol. Nem é de estranhar que se encontre na igreja de São Miguel o estilo barroco italiano e não espanhol, se considerarmos que o seu construtor foi o Irmāo arquiteto milanês, Gian Battista Primoli.

Este último ingressou na Companhia de Jesus aos 43 anos de idade, com o objetivo de dedicar sua vida profissional às grandes construções que se projetavam então nas Missões da América.

Chegou a Buenos-Aires em julho de 1717, com a numerosa expedição que, embarcada em três navios, havia partido de Cádiz dois meses antes. Na mesma expedição vieram outros artistas notáveis, entre os quais o Irmāo arquiteto romano Andrea Bianchi. Os nomes dêsses dois arquitetos ficaram ligados à realizaçāo dos grandes monumentos coloniais de Córdoba e Buenos-Aires. Todavia os historiadores não estão sempre de acôrdo sôbre a parte que toca a cada um dêles na construção dêsses grandiosos monumentos.

O erudito Padre Guilhermo Furlong S. J., contràriamente à opinião até aqui geralmente aceita, afirma que raras vêzes terão os dois arquitetos trabalhado em colaboração. E inegável, entretanto, que tenham seguido a mesma escola e exercido um sôbre o outro grande influência: a igreja de Sāo Miguel, cuja autoria todos os historiadores estāo de acôrdo em atribuir a Primoli, tem sua fachada muito semelhante à fachada da antiga Catedral de Buenos-Aires, cujo projeto, segundo o Padre G. Furlong, teria sido obra exclusiva de Bianchi.

Embora viesse destinado às construçōes a erigir em Missōes, só em 1730 pôde Primoli deixar Buenos-Aires e Córdoba, onde era solicitado para tantas e tão importantes iniciativas.

Na regiāo missioneira, Gian Battista Primoli construiu as três grandes igrejas dos Povos de Concepción, Trinidad e Sāo Miguel.

São Miguel era desde 1697 a maior e mais importante das Missōes. A igreja velha nāo bastava para conter a massa da populaçāo, tendo sido essa uma das razōes apresentadas para o desmembramento do Povo. 
Não sabemos precisar a data da chegada de Gian Battista Primoli a São Miguel. Mas em 1735 estavam já iniciadas as obras da igreja, quando foi êsse arquiteto chamado a Buenos-Aires para dirigir a construção da igreja de San Telmo, projetada por Andrea Bianchi.

Em 1737 voltou Primoli às Missōes e até 1744 trabalhou na igreja de São Miguel, empregando diàriamente 80 a 100 operários.

Não só no caráter e plástica geral difere a igreja de São Miguel das demais igrejas missioneiras, mas também no sistema construtivo. As florestas tropicais induziram os construtores jesuiticos ao emprêgo da madeira como principal elemento de suas estruturas: os madeiramentos dos telhados e os forros de madeira apoiavam-se por meio de vigas em pilares feitos de troncos de grandes árvores. Esses pilares eram depois incorporados às paredes externas. No caso de igreja de três naves, eram também de madeira as colunas intermediárias, ficando à vista no interior do templo. "De êste modo", disse Cardiel, "carga toda la fabrica del tejado en los pilares y nada en la pared".

Ao padre Antônio Sepp, vindo de uma regiāo da Europa central onde são abundantes as matas, já era familiar essa maneira de construir.

Já não era assim com o arquiteto Gian Battista Primoli. Imbuído da tradição da construçāo italiana, nem o deteve a falta de cal, que muito dificultava a construção em Missōes: a igreja de São Miguel foi totalmente construída de pedra até a altura dos tetos.

Os elementos subsistentes da igreja de São Miguel permitem a determinação de quase tôdas as suas disposiçōes em planta. Do levantamento feito resultou uma igreja com três naves, sem transepto (fotos 16 e 17). De um e do outro lado do corpo da igreja, duas tôrres de planta quadrangular davam à fachada principal seu máximo desenvolvimento.

Precedia o templo um largo pórtico constituído por sete arcos, recaindo sôbre pilares ornados por colunas engastadas.

A nave principal era separada das colaterais por duas fileiras de arcos, cujos pilares eram também ornados por pilastras conjugadas (foto 18).

Os pilares das arcadas eram ainda munidos de contrafortes, nos quais se apoiavam arcos transversais, dividindo os colaterais em cinco capelas. Vemos nos contrafortes do colateral direito (foto 19) a nascença dêsses arcos claramente indicada pela disposição das pedras em satiencia.

Sôbre a entrada da igreja era provàvelmente localizado o côro em piso elevado, e onde teria sido instalado o grande órgão. A foto 20 mostra os buracos deixados nas paredes pelos barrotes que suportavam êsse piso. 
A direita da entrada encontrava-se uma capela com seu altar e pia batismal, sendo a bacia de barro vidrado de verde, assentada sôbre uma moldura de talha dourada.

A nave principal conduzia a uma capela-mor de pequena profundidade.

De um e do outro lado da capela-mor estavam dispostas salas que comunicavam a igreja com um espaçoso salão, em forma de $T$, com dois
compartimentos anexos.

Sôbre os elementos em elevação, as ruinas da igreja de São Miguel não formecem dados suficientes. Dos tetos nada resta. Infelizmente, não encontramos nos autores que conheceram as Missões os esclarecimentos necessários. O historiador D. Félix de Azara, que viu São Miguel em fins do século XVIII, informa apenas que a igreja tinha " 100 varas de longitud $y$ es de silleria hasta la cornisa, sin más cal o mezcla que en las juntas por fuera; el resto es de madera como en todas."

No interior, a nota dominante é a estrutura formada pelos maciços recebendo as descidas dos arcos e contendo uma ordem de pilastras conjugadas. No alto, o entablamento dessas pilastras segue ao longo das paredes da neve. $O$ aspecto de certas pedras do muro do frontispicio, pelo lado interno, indica que o fôrro da nave vinha morrer sôbre êle segundo um arco em asa de cesta (foto 21).

De cogitação em cogitação, chegamos à conclusão de que diretamente sôbre a cimalha, apoiar-se-ia uma abóboda de berço, reforçada pelos arcos salientes, em correspondência com as pilastras. tesse berço levaria lunetas com aberturas para a iluminação (foto 22), conforme indicam os vãos deixados na parte superior das paredes longitudinais da nave (foto 18).

$O$ berço da nave principal era, a nosso ver, coberto por telhado de duas águas: as paredes da nave sobem além da nascença do berço para recebê-lo. t nessas paredes que vemos os vãos das janelas de triforium, destinadas a iluminar a nave por cima dos telhados dos colaterais.

Os tetos dos colaterais eram, provàvelmente, berços interrompidos pelos tímpanos dos arcos que separavam as capelas e penetrados por lunetas, de certo protegidos por telhados de uma água (foto 22). Isso é evidente, pelo fato de terminarem os contrafortes dos maciços, que separam a nave dos colaterais, a uma altura de $10,60 \mathrm{~m}$, com uma inclinação que nos dá o caimento dêsse telhado (foto 19).

Quando à capela-mor, dada a sua finalidade, teria também teto em berço, que seria construído no prolongamento do berço da nave, e separado dêste por um arco saliente do teto da nave, pois que nāo encontramos qualquer indicio de outro arco-cruzeiro. 
O altar-mor com tôda a probabilidade foi erigido contra o muro dos fundos, ocupando a largura da capela-mor. Tanto assim que se vêem muito claramente os buracos deixados pelas peças de madeira que manteriam a talha do respectivo retábulo.

Pelas disposiçōes dêsses buracos podemos supor que o retábulo do altar-mor era composto de quatro elementos verticais, quiçá constituindo colunas conjugadas, em três ordens superpostas, separando nove quadras que continham os nichos para as imagens (foto 24). O nicho que ficava acima da cimalha guardaria a grande imagem de São Miguel Arcanjo, de que nos fala o padre Gay.

Essa nossa suposição é tanto mais verossímel que o retábulo assim disposto se assemelha perfeitamente ao da igreja de la Compañia em Córdoba.

Colunas, entablamentos, impostas e arquivoltas teriam emoldurado os nichos; guarniçōes e pinturas enriqueceriam o altar mor, assim feito para atrair todos os olhares; a ornamentação do resto da igreja devia ser sóbria, sem a profusão de motivos escultórios e pictóricos que ostentaram as igrejas em época posterior.

Quanto ao aspecto exterior, a fachada principal é a parte mais conservada do monumento (foto 25 ).

Os elementos subsistentes permitiriam sua completa representação se não faltassem dados positivos sôbre a cobertura das tôrres e sôbre a cobertura do pórtico.

Para representação de uma e outra das coberturas, encontramos, felizmente, um precioso indicio na gravura do historiador francês Demersay, que viu a igreja em 1846, antes da destruição dêsses elementos (foto 26).

A forma da cobertura da tôrre do lado esquerdo aparece nessa gravura, embora muito deformada pela perspectiva, como uma campânula ou um sino, encimado por uma bola e uma cruz.

Veremos, adiante, como a fachada da igreja de São Miguel se assemelha à antiga fachada da Catedral de Buenos-Aires, executada pelo mesmo arquiteto, ou por seu compatriota, colega de Companhia e notável arquiteto Andrea Bianchi. Na cobertura das tôrres dessa igreja, bem como na de outros templos do mesmo periodo em Buenos-Aires - Santo Domingo, San Nicolas, El Pilar - encontramos a forma mais ou menos acentuada de campânula que adotamos em nossa reconstituição.

Segundo foi observado por Vicente Nadal Mora, em sua obra La Arquitectura Tradicional de Buenos Aires, era essa a forma mais empregada na época, não sendo tão comum o tipo de cúpola bulbosa que cobre o campanário de La Merced. 
Sôbre a cobertura das tôrres havia um galo amarelo, provàvelmente de cobre. O frontispicio do pórtico aparece na gravura de Demersay encimado por um frontāo.

O historiador José Feliciano Fernandes Pinheiro, ao invés de um teIhado de duas águas, parece fazer referência a uma cobertura em terraço.

Preferimos admitir esta hipótese, porque nos repugnava a idéia de um telhado indo morrer de encontro à fachada, sem respeito pela modenatura elaborada que esta apresenta. Vemos nas ruínas da fachada do corpo da igreja (foto 25) vestígios dos apoios do vigamento que suportava êsse piso.

Analisando, porém, a igreja nesta primeira tentativa de reconstituição, estranhamo-lhe certas disposições e chegamos à conclusão de que essa construção não correspondeu exatamente ao projeto grandioso que suas proporçōes indicam.

Com efeito, a capela mor resultou do fechamento da última arcada da nave. Pareceu-nos acanhada, sem profundidade, enquanto atrás dela foi deixada uma sala, cujas dimensōes, forma e caráter suntuoso não justificam seu destino como sacristia (foto 27). Acresce que êsse salão é ladeado por salas menores que conviriam perfeitamente à finalidade de sacristias, principalmente a da esquerda, que comunica a igreja com o Colégio dos Padres.

Se, por fim, viermos a fazer abstração da parede que separa as naves da igreja da sala dos fundos, melhoram tôdas as proporçōes, e a planta toma o aspecto que lhe convém (foto 28) : transepto com a mesma largura da nave principal, capela mor de suficiente profundidade, ligada à sacristia por uma rica porta, em sítio perfeitamente adequado às exigências da liturgia; e passagem do transepto para a capela mor assinalada por um chanfro nos pés direitos e por pilastras conjugadas que suportariam 0 arco-cruzeiro.

Outro argumento no mesmo sentido é a não existência de amarração da alvenaria dêste muro, que veio formar a capela mor, com a dos pilares da nave. $O$ muro foi construido depois de prontos os pilares: sua alvenaria é menos regular, e, além de tudo, veio morrer de encontro a êsses pés direitos, sem o menor respeito pelas pilastras que cobriu, deixando, entretanto, de fora, parte dos capitéis como testemunha (foto 18).

Considerando essa hipótese da igreja ter um transepto, o fôrro dêsse transepto deveria ser abobadado em berço e, no encontro com 0 berço da nave principal, teria sido prevista a clássica cúpola sôbre pendentes. Essa cúpola elevar-se-ia sôbre um tambor, no qual seriam deixados os vãos para iluminação (fotos 29,30 e 31 ).

As disposiçōes da igreja, assim concebidas, assemelham-se às dos monumentos executados anteriormente pelo mesmo arquiteto, quer trabalhando 
sòzinho, quer em colaboração com o notável arquiteto Andrea Bianchi, em Misiones, Córdoba e Buenos-Aires.

As grandes igrejas: - a Catedral de Buenos-Aires, a Catedral de Córdoba e principalmente a igreja de San Ignacio, em Buenos-Aires - muito se lhe assemelham; todos êsses templos se filiam ao imponente tipo da igreja de Gesu, de Roma, com seu transepto de pequena extensão, tendo o cruzamento das naves coroado por cúpola sôbre tambor elevado (fotos 32 e $33-a-b-c-d)$.

Nas pequenas igrejas de Alta Gracia e de Santa Catalina, em Córdoba, o transepto quase desaparece, mas a capela mor é sempre precedida pela cúpola sôbre pendentes (fotos 32 e $33-e-f$ ).

Ésses tetos curvos, abóbadas de berço e cúpolas, foram construídos de alvenaria, com a proteção suplementar de um telhado ou sem ela.

De alvenaria eram também as abóbadas da igreja de La Trinidad, no Paraguai, construida em 1744 pelo arquiteto Gian Battista Primoli, conforme nos informam os Inventários de 1767.

Ante os elementos citados, a conclusão inevitável é que a igreja de São Miguel foi projetada com uma nave transversal e cúpola sôbre tambor elevado.

Tal cúpola certamente não chegou a ser construída. Obra de tamanha importância, teria impressionado os homens de então, provocando comentários que não deixariam de chegar até nós.

$\mathrm{Na}$ impossibilidade de realizar o projeto inicial da igreja, quais teriam sido nessa hipótese as modificaçōes introduzidas pelos seus construtores?

Sôbre a forma dos tetos e coberturas da igreja de São Miguel, apenas duas referências encontramos nos autores consultados. A primeira foi feita pelo Cônego João Pedro Gay, na descrição seguinte: "O corpo da igreja era de três naves, com seu cruzeiro e meia laranja, com trezentos e cinqüenta palmos de comprimento de vāo, com cento e vinte de largura e quarenta e cinco palmos de pé direito..." a segunda foi feita pelo professor Miguel Solá e parece louvar-se na descrição do Padre Gay: "La planta era de trés naves y cúpola en el crucero; tenia 73 metros de largo por 25 de ancho".

A referência do Padre Gay evidentemente se baseou em informaçōes, pois a igreja, ao tempo de seus escritos, já estava sem cobertura. Nem a grande parede que separa as naves da sala dos fundos, à qual êle não alude, permitiria a existência de transepto e cúpola. 
A hipótese mais provável, portanto, é que a igreja tivesse sido concluida, com seu cruzeiro e "meia laranja", diferindo do projeto inicial apenas na construçāo da cúpola menos elevada. Ficaria ela, nesse caso, inteiramente de acôrdo com a descrição do Padre Gay, medindo os trezentos e cinquienta palmos de comprimento, da porta de entrada principal à parede do fundo da capela mor.

Assim teria sido a igreja até 1756, quando provàvelmente ficou sem cobertura, em consequência do incêndio e das depredaçōes que sofreu por ocasiāo da guerra dos Sete Povos.

Com o restabelecimento da Missão, em 1761, os jesuitas, na premência de retomar os serviços do Culto e sem os recursos materiais que a recomposiçāo total da igreja exigia, teriam construído a espêssa parede que limitou a profundidade da nave.

Năo acreditamos tenham os Padres cogitado na possibilidade de em qualquer tempo retomar a construção da igreja de São Miguel, de acôrdo com o projeto primitivo, porque:

$10^{\circ}$ - o muro que limita a profundidade da nave sobe até uma altura de $15.00 \mathrm{~m}$ com $1,75 \mathrm{~m}$ de espessura;

3. - conforme já dissemos, o altar mor deve ter sido construído contra êsse muro;

$3 .^{\circ}-\mathrm{e}$, finalmente, porque faltam nas ruinas as duas últimas arcadas do lado esquerdo da nave e foi demolido até o chāo o pé direito que as suportava (foto 18). Ora, a falta dêsses elementos, que se poderia lastimar entre os danos sofridos pelo monumento, atribuímo-la a uma demoliçăo deliberada em vista da criação de um nôvo transepto. Os trabalhos teriam sido nesse ponto interrompidos, porquanto as arcadas do lado direito da nave se mantêm inalteradas (foto 18 ).

\section{III - DO COLEGTO}

Para a reconstituição do Colégio baseamo-nos principalmente nas indicaçōes fornecidas pelos elementos subsistentes, embora sejam êsses apenas: a) muros em ruinas, os quais, se em alguns pontos atingem $3.50 \mathrm{~m}$ de altura e noutros apresentam ainda $1.00 \mathrm{~m}$, na maior parte se encontram completamente tombados, tendo apenas os alicerces; b) bases ou simplesmente alicerces de bases de pilares, alinhados ao longo dêsses muros.

- Colégio era constituído por uma série de casas, situadas em volta de dois grandes pátios, e abrindo-se sôbre os mesmos através de alpendres ou pórticos construidos com pilares de pedra (foto 34 ). 
Um bonito portāo, cujo aspecto nos foi conservado pela gravura de Demersay (foto 35 ), dava acesso ao primeiro pátio, contiguo à igreja. O portão se localizava à distância igual das extremidades do pátio.

Nâo encontramos nenhum vestigio de muro nem alicerce de colunas no lado do claustro que faz face à igreja. Acreditamos, entretanto, que os pórticos se seguissem por êsse lado, correndo aproximadamente no alinhamento da tôrre, e que o espaço resultante para trás do pórtico até à igreja fôsse ocupado por salas de aula do Colégio.

Essa hipótese é baseada na descrição feita pelo Pe. Luís Gonzaga Jaeger S. J. de um Povo que pensamos ser São Miguel. Confirma-a a disposição dos muros da fachada lateral da igreja, os quais sobem até à altura dos peitoris das janelas dos colaterais com uma espessura maior do que aquela que irão ter daí por diante. Na saliência assim formada se apoiaria o telhado que cobria as salas de aula e seu alpendre (foto 34-e).

O fato de não se ter ai encontrado elemento algum de construção justifica-se pelas escavaçōes a que procediam ao longo dos muros a curiosidade e a cobiça do povo, empenhadas em descobrir os fabulosos tesouros enterrados pelos jesuitas.

Assim constituido, o pátio mede $66.30 \mathrm{~m} \times 63.50 \mathrm{~m}$. Essas dimensōes concordam aproximadamente com as fornecidas pelo Cônego J. P. Gay para Missões da mesma importância: 300 palmos $\times 300$ palmos.

O Colégio de São Luís tinha quatorze pilares na frente dos quartos dos Padres e treze nas outras faces do claustro. O claustro de São Miguel apresentaria quatorze pilares em cada uma de suas faces, se no ângulo NO as arquitraves não se apoiassem nas paredes da tôrre.

Ao fundo do pátio achava-se a ala principal com a residência dos Padres. Ao centro devia ficar a sala do Padre Reitor, onde, segundo os historiadores Bach e Pfotenhaeur "reinava uma semi-obscuridade mágica". Do lado esquerdo ficavam provàvelmente os aposentos destinados aos demais jesuítas, todos amplos e confortáveis; do lado direito o refeitório "com lindas portaladas, que serviriam magnificamente bem para capelas" no dizer do Cônego João Pedro Gay. Ainda, segundo êsse autor, o refeitório devia ter subterrâneo mais ou menos extenso.

Interrompem-se ai os muros com indicação de ter havido uma passagem coberta do pátio para a quinta dos Padres.

Seguiam-se na mesma ala cozinha e dispensa, se adotarmos disposiçāo semelhante à da Missão de San Ignacio Mini, reconstituida por Juan Queirol (foto 15-b). 
Nas casas que vêm, em seguida, na ala paralela à igreja, eram provàvelmente instaladas as oficinas de ourives, pintores, entalhadores, encadernadores, e uma pequena tipografia. Ai ficava ainda uma casa forte para prisão.

Atravessando pequena passagem coberta, que vemos claramente indicada nas ruinas, passava-se ao segundo pátio.

Os elementos subsistentes nas ruinas nos mostram que, em três de suas faces, havia construçōes abertas sôbre o pátio através de pórticos ou alpendres.

Do mesmo lado em que ficavam as residências dos Padres, no primeiro pátio, ficavam, provàvelmente, no segundo: os armazéns, onde eram guardadas as sementes e o produto das colheitas; os depósitos onde se armazenava a roupa antes da distribuição; os arsenais de armas.

Nos outros lados ficavam provàvelmente: a usina de açúcar, com seus cinco ou seis caldeirōes; as oficinas dos tecelōes, que chegavam a ocupar quarenta e até cinqüenta teares; as oficinas dos alfaiates, sapateiros, chapeleiros; as oficinas dos carpinteiros, ferreiros, serralheiros, latoeiros, curtidores; as oficinas de consêrto de carruagens.

\section{IV - DAS CASAS DOS INDIOS}

Sôbre a construção das casas dos indios pouco esclarecem as ruinas.

As inúmeras bases, alicerces de bases e capitéis encontrados serviram, no entanto, para determinar sua localização e para evidenciar:

$1 .^{\circ}-$ que as ditas casas eram rodeadas por alpendres compreendendo três vãos ou intercolúnios em seu lado menor;

$20^{\circ}$ - que no outro sentido a respectiva fachada devia ter ora oito, ora nove intercolúnios;

$3 .^{\circ}-$ que a distância entre os pilares era quase sempre de $5.10 \mathrm{~m}$ de
a eixo; eixo a eixo;

4..$^{\circ}$ - que os pavilhōes eram separados uns dos outros por uma distância de $12.00 \mathrm{~m}$, largura das ruas;

$5 .^{\circ}$ - que os pilares dos pórticos ou alpendres tinham fuste de secção quadrada, com $0.35 \mathrm{~m}$ de lado;

6. - que êsses fustes eram fixados às bases e capitéis por meio de encaixes de secção quadrangular. 
Os escritos do tempo e as descrições dos historiadores ajudaram-nos a completar a reconstituição.

- Padre Luís Gonzaga Jaeger dá-nos para tais alpendres uma largura de $2.00 \mathrm{~m}$ a $3.00 \mathrm{~m}$. Os alpendres do Colégio têm a largura de $2.50 \mathrm{~m}$ de parede a eixo dos pilares; adotamos a mesma medida para os alpendres das casas dos indios, que não seriam positivamente mais largos que os pórticos do Colégio (fotos 34-a-b-c).

Deduzidos os alpendres, sobra em cada pavilhão uma área de $10.00 \mathrm{~m} \times$ $\times 35.00 \mathrm{~m}$ ou $10.00 \times 40.00 \mathrm{~m}$, conforme o caso. Esta área seria dividida no sentido do maior comprimento por uma parede mestra e no sentido transversal, por paredes divisórias, formando ao todo quatorze (ou dezesseis) compartimentos, destinados cada um à moradia de uma família. Esses compartimentos seriam providos de porta e janela.

Façamos um parêntese para considerar quão rudimentares eram essas disposições, constando de um só compartimento para satisfazer as necessidades de moradia de tôda uma familia!

Não se poderá melhor comentá-lo do que empregando as palavras do Padre Antônio Sepp: "E dentro da casa - onde está a saleta? Onde o dormitório, a cozinha, adega, dispensa, e onde o vinho e a cerveja na adega, e onde as panelas e as bacias de estanho na cozinha, e onde a cama no dormitório? Tudo isso os indios têem reunidos numa só peça.

A pobreza dêsses domicilios, comparada ao tratamento pomposo dos monumentos, chegou a provocar comentários até na Europa.

Os blocos de moradia deviam ser cobertos por telhados de quatro águas, à semelhança dos pavilhōes dos Povos de São João (foto 13) e da Candelária (foto 14).

A disposição das paredes internas evitava o emprêgo de tesouras no madeiramento. Com efeito, os caibros podiam apoiar-se na parede mestra divisória; depois, nas terças, apoiadas por sua vez nas paredes transversais, nas paredes externas e, finalmente, nas vigas que ligavam os pilares do alpendre. Os espigões das garupas apoiavam-se no encontro das paredes divisórias, no encontro das paredes externas e finalmente nos ângulos do alpendre, sôbre os pilares, ficando assim fortemente estabelecidos.

Com a reconstituição das casas dos indios chegamos ao fim do programa proposto em nosso trabalho.

Na Reconstituicãa do Povo de São Miguel procuramos destacar os dois aspectos da contribuição que oferecemos: 
1) Alguns dados exatos, baseados no estudo detido das ruinas;

2) Conjeturas para serem discutidas, combatidas ou aceitas, provocando assim nos meios estudiosos um movimento de interêsse $e$ outras contribui६ōes, em tôrno do assunto, certamente mais valiosas.

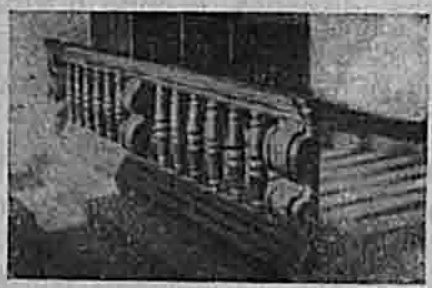




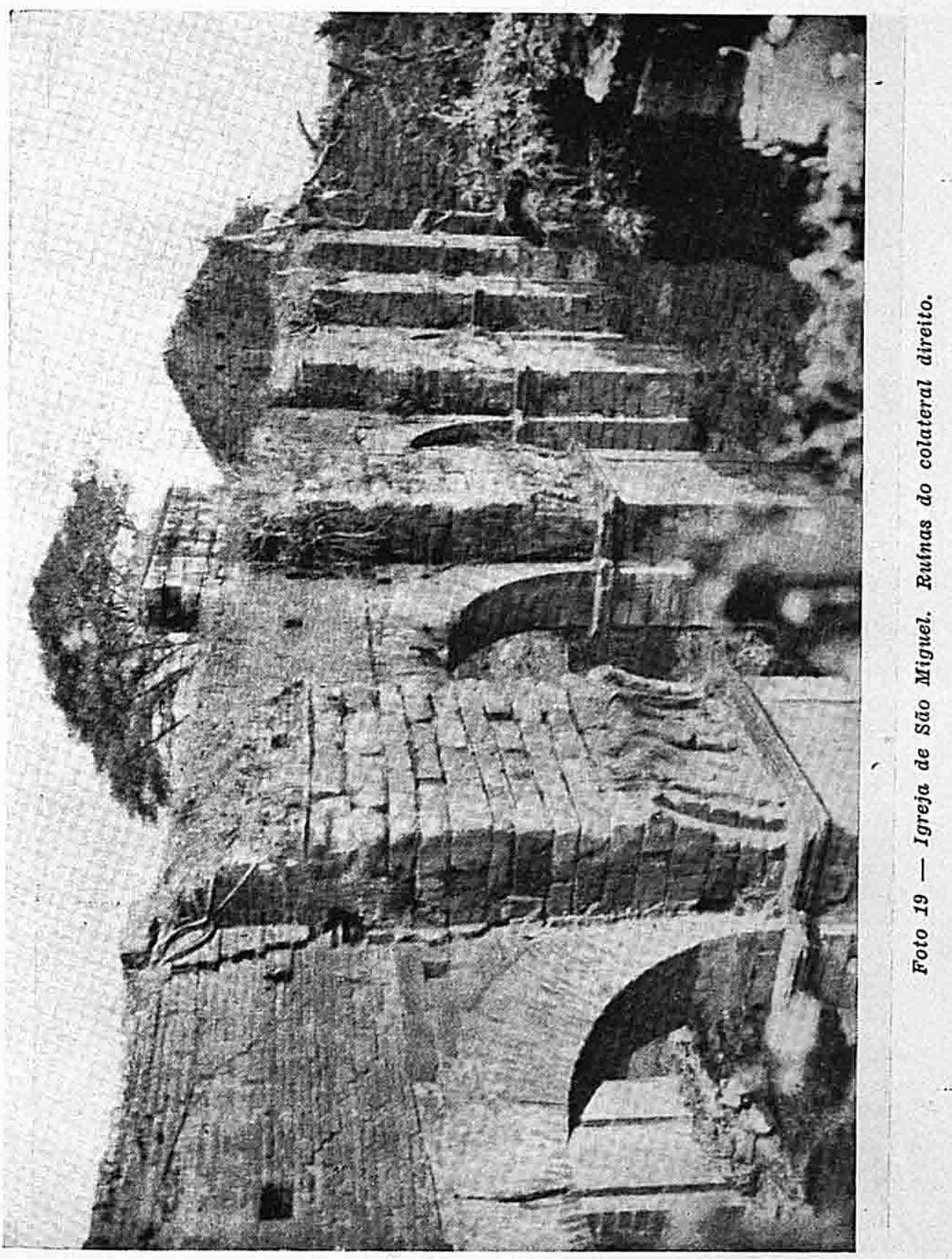




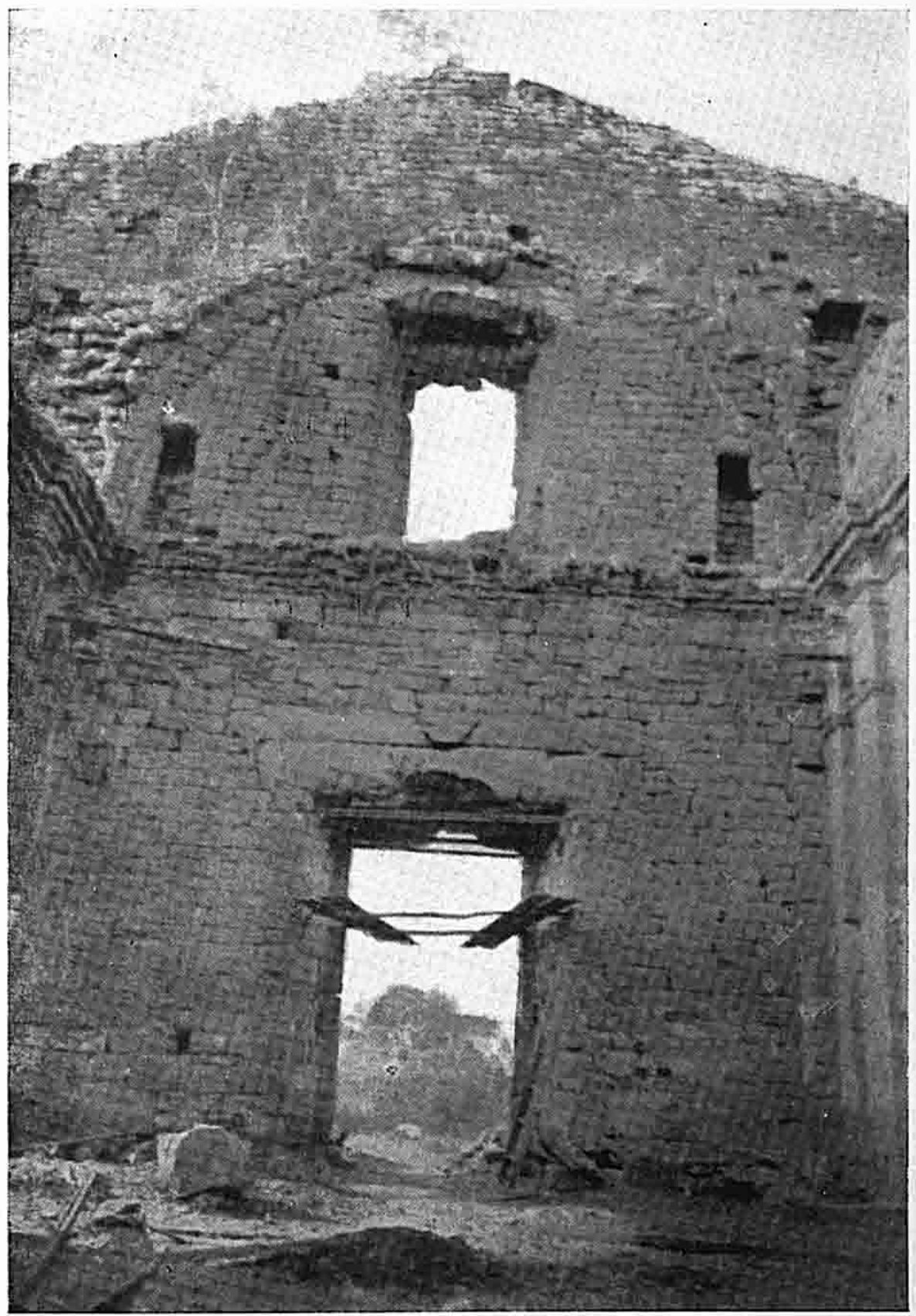

Foto 21 - Igreja de São Miguel. Ruinas do frontispicio, face interna. 


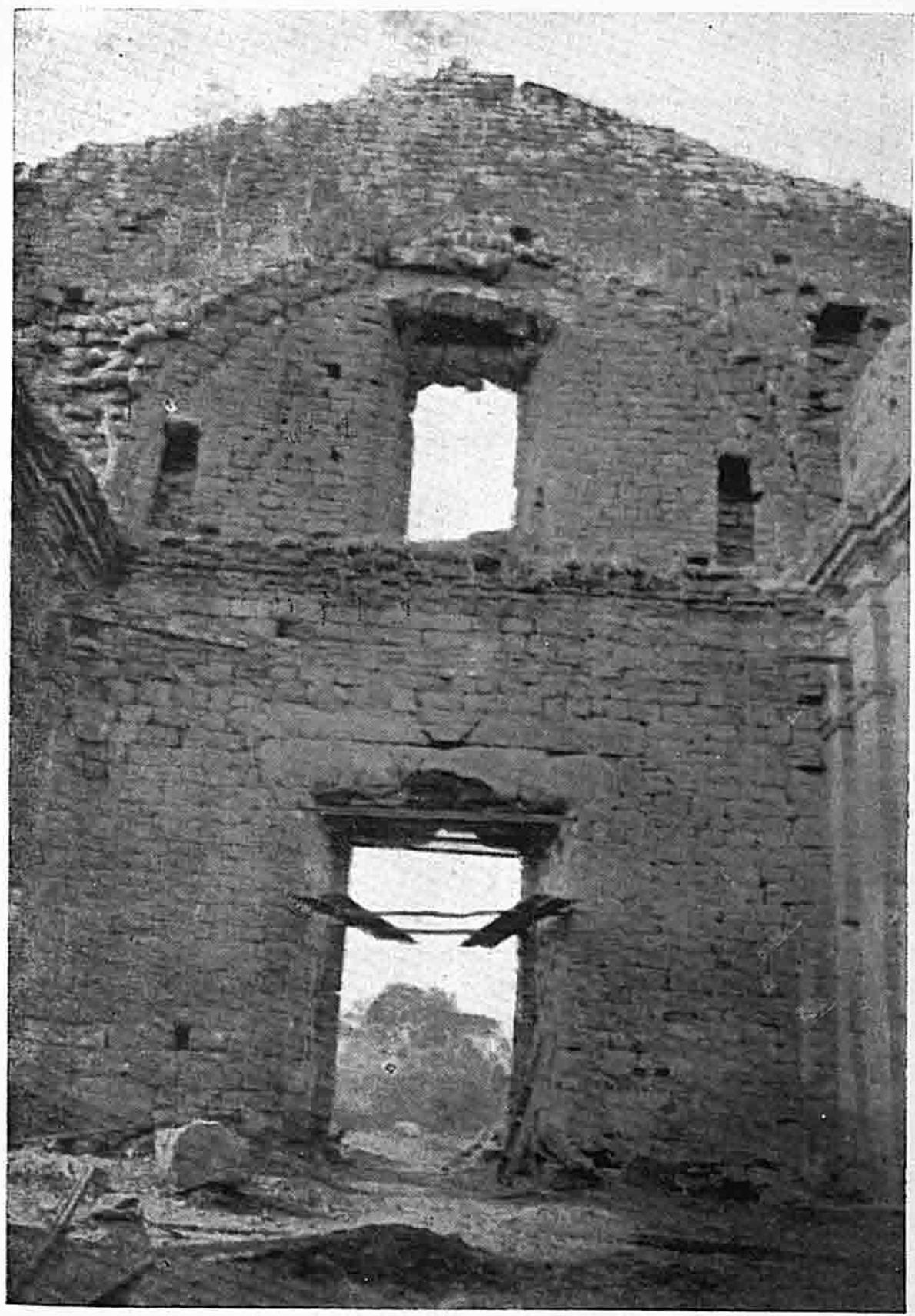

Foto 21 - Igreja de São Miguel. Ruinas do frontispicio, face interna. 


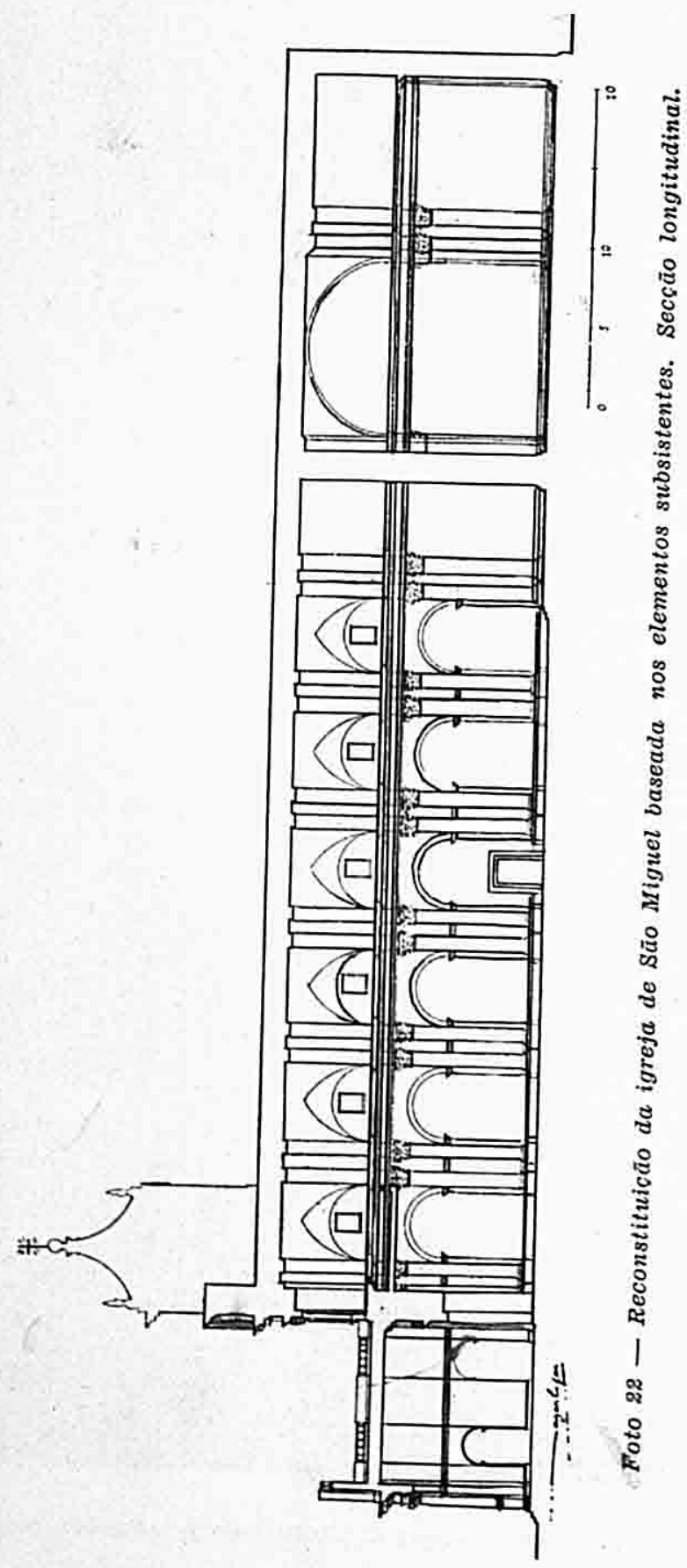




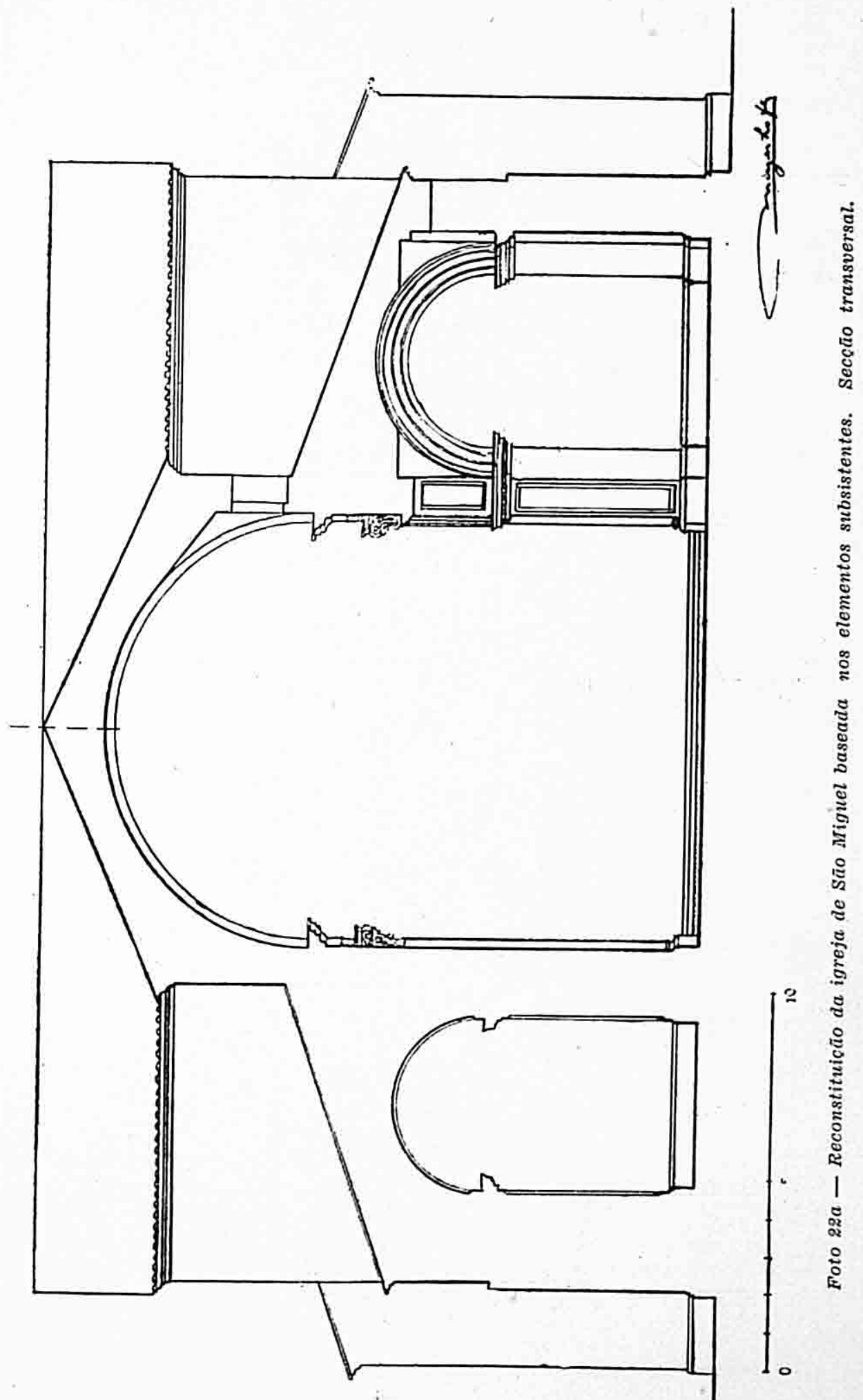




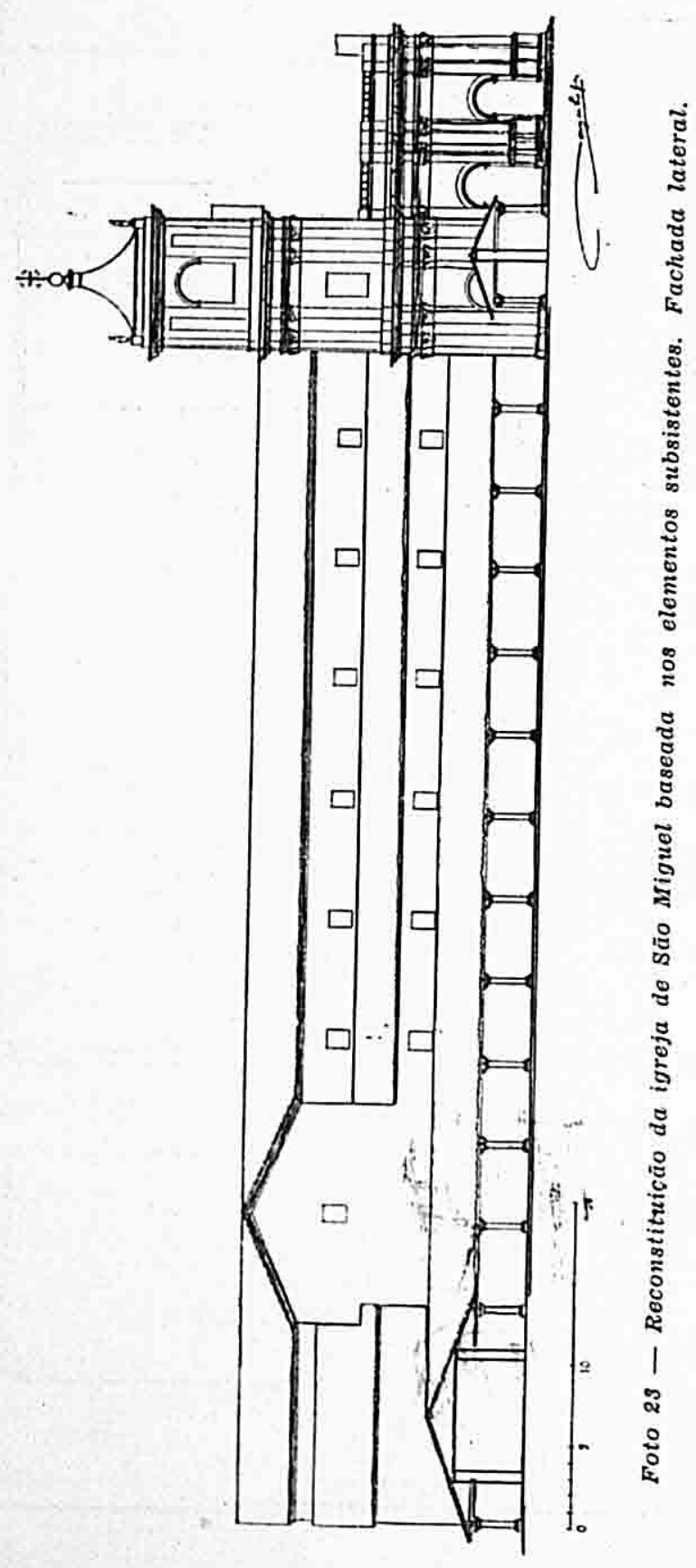




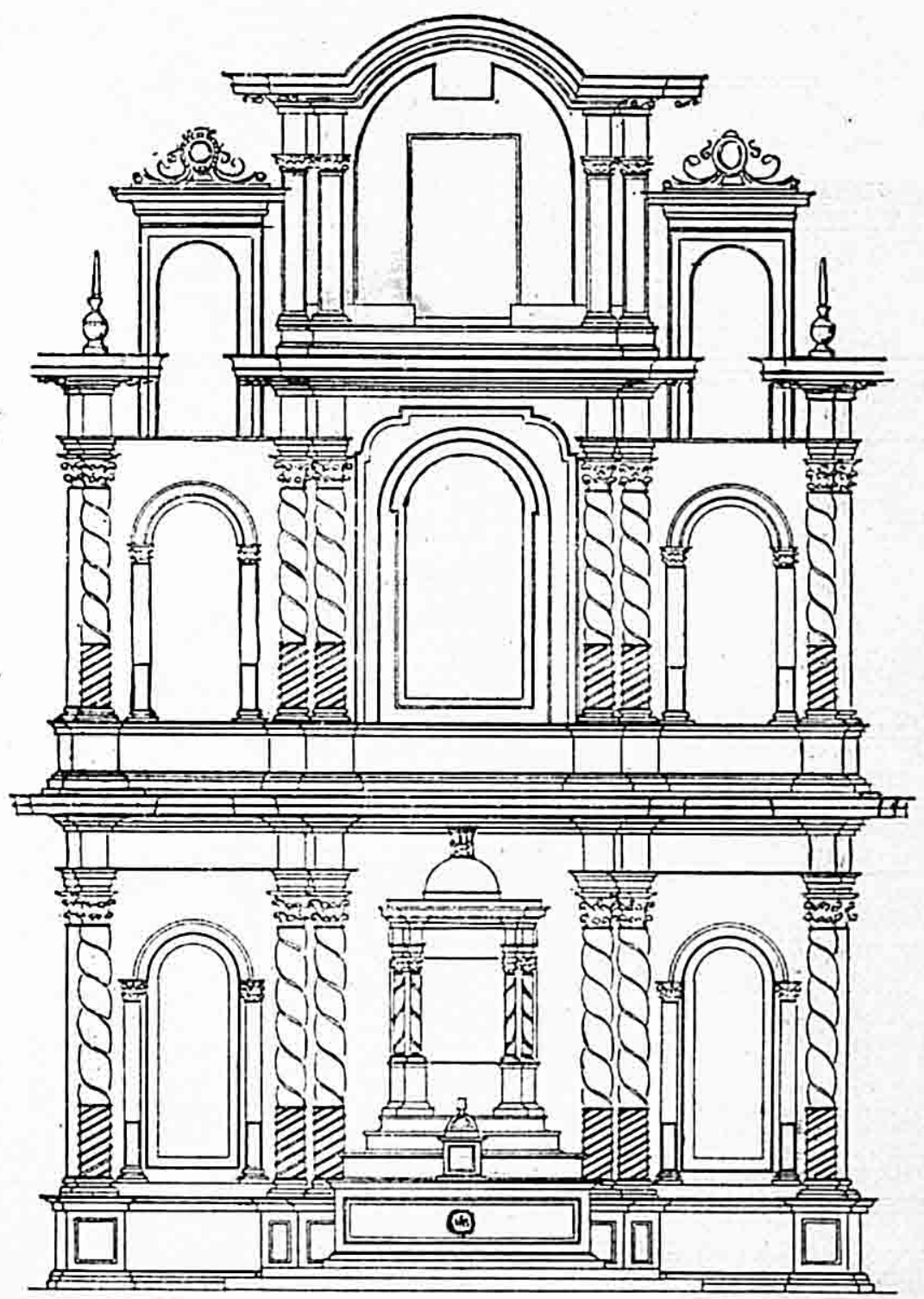

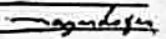

Foto 24 - Reconstituicão da igreja de São Miguel baseada nos elementos subsistentes. Retábulo do altar-mor. 


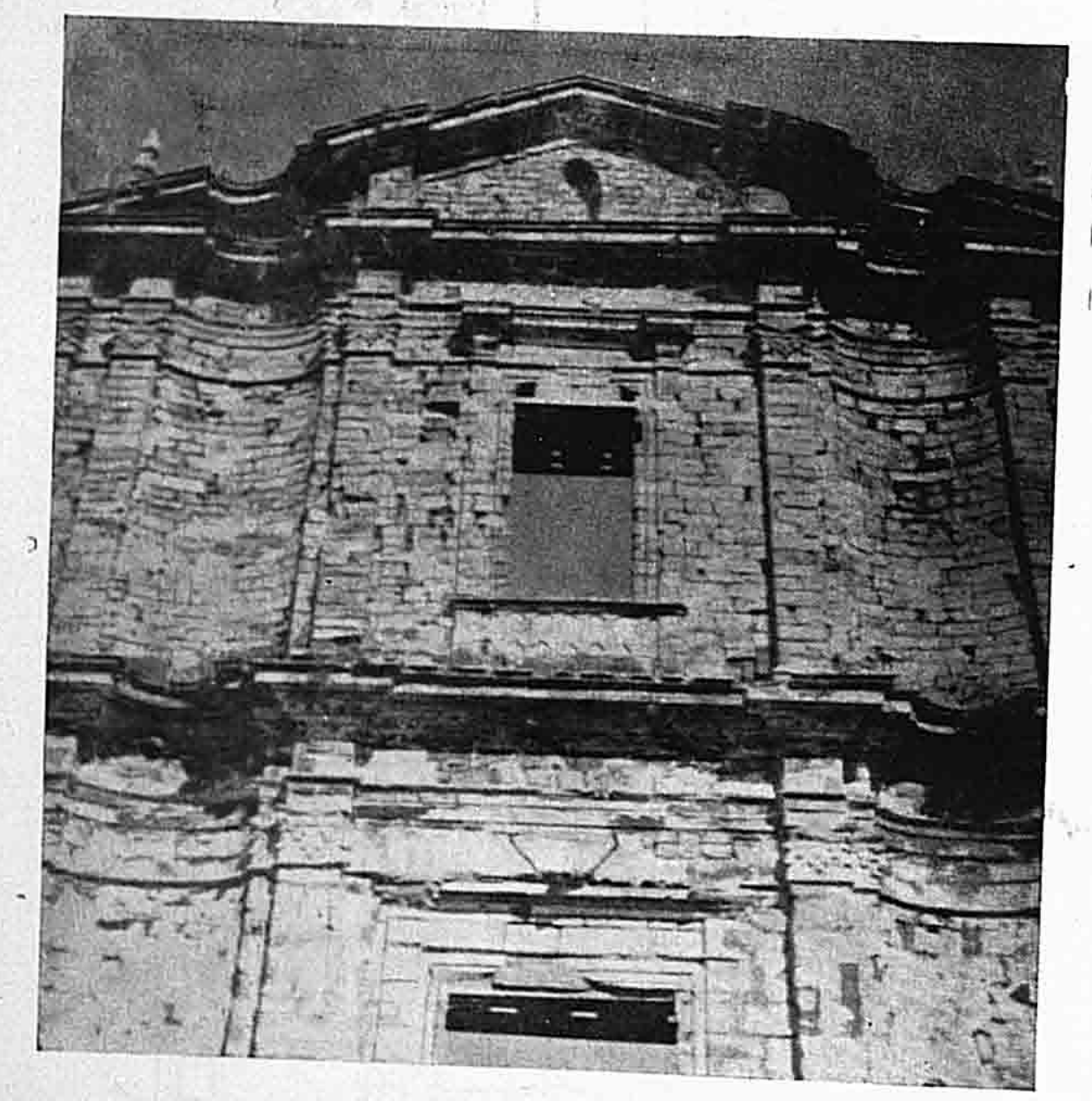

Foto 25 - Ruínas da igreja de São Miguel. Detalhe da fachada principal. 


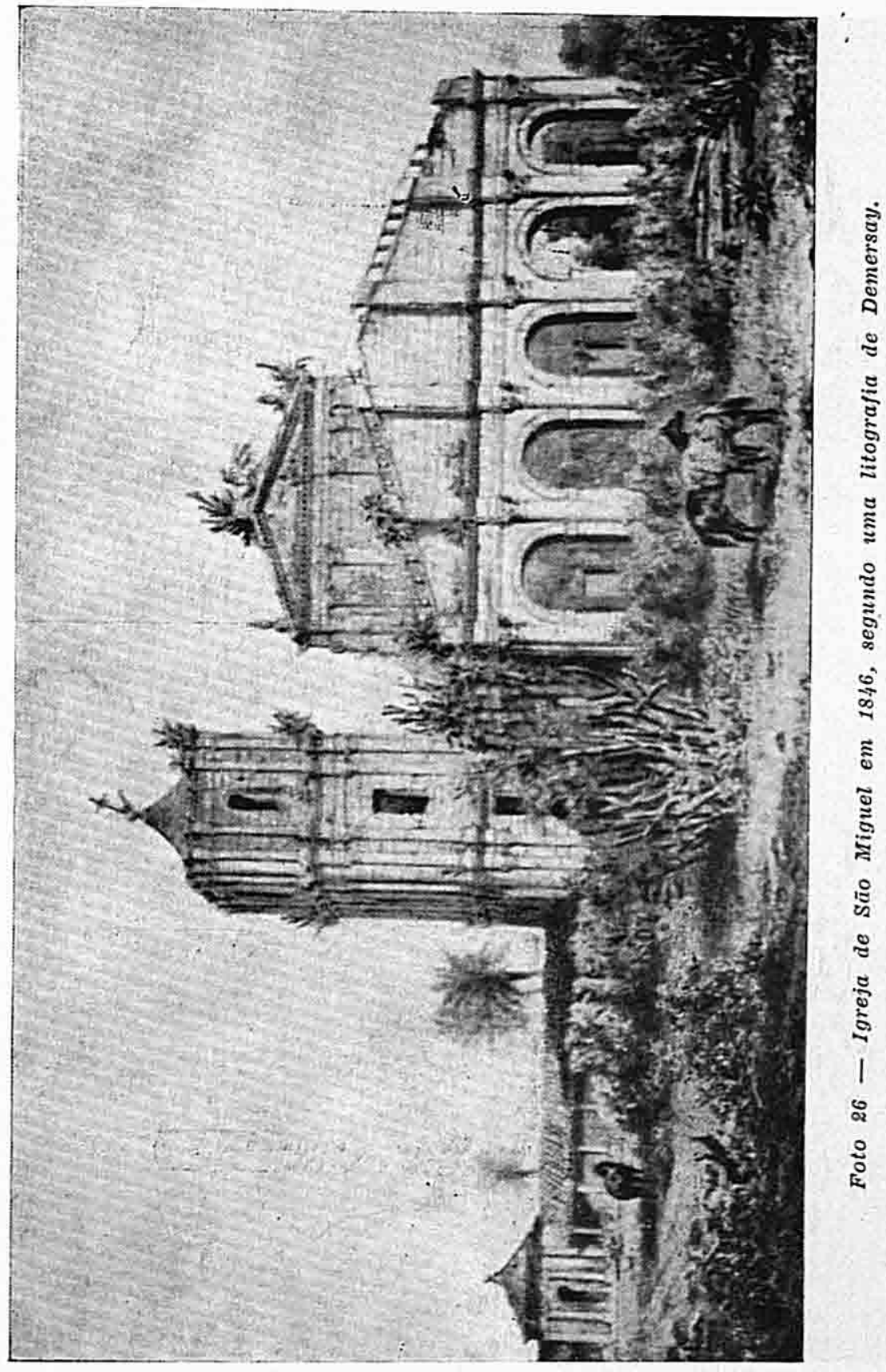




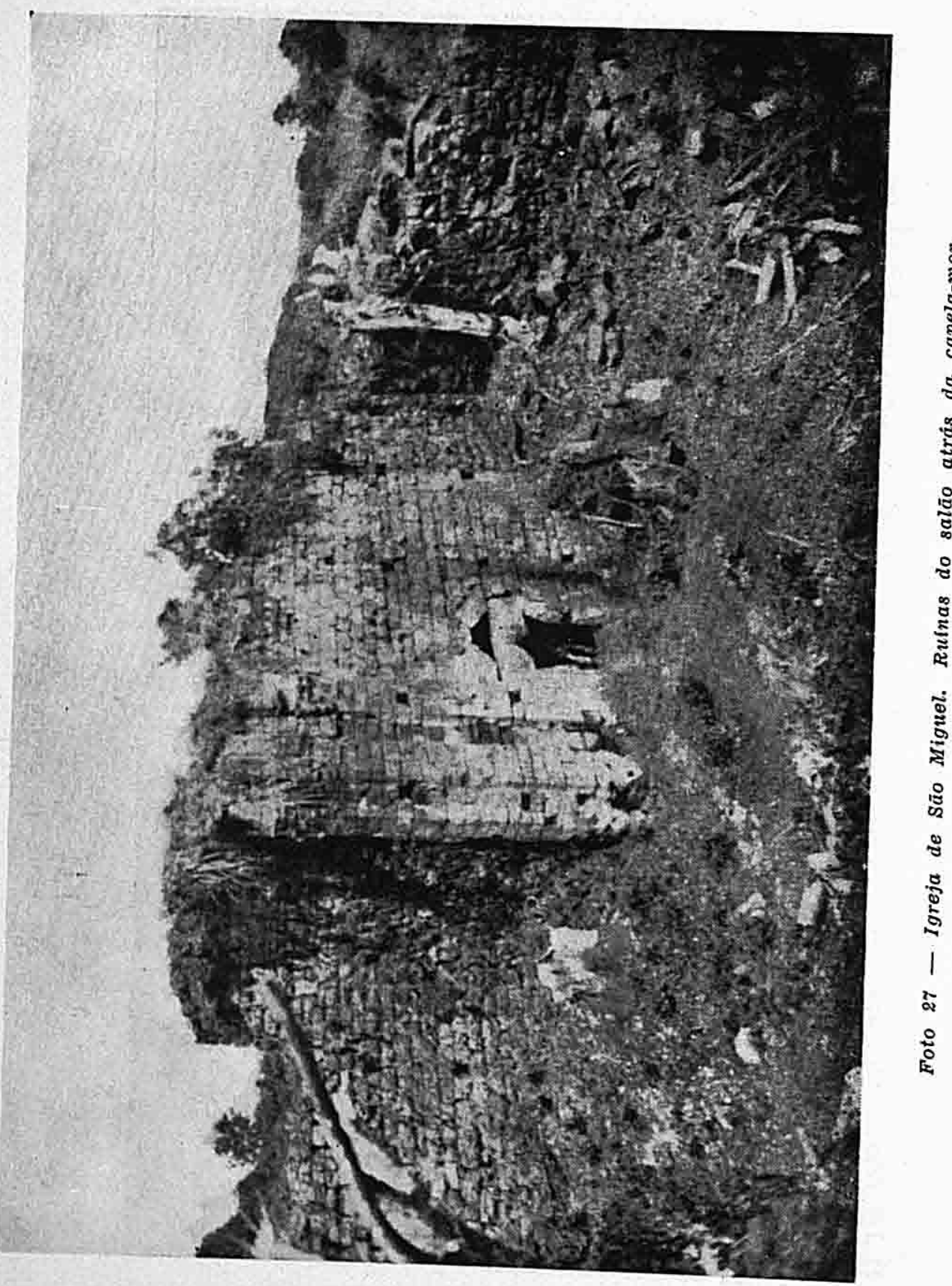




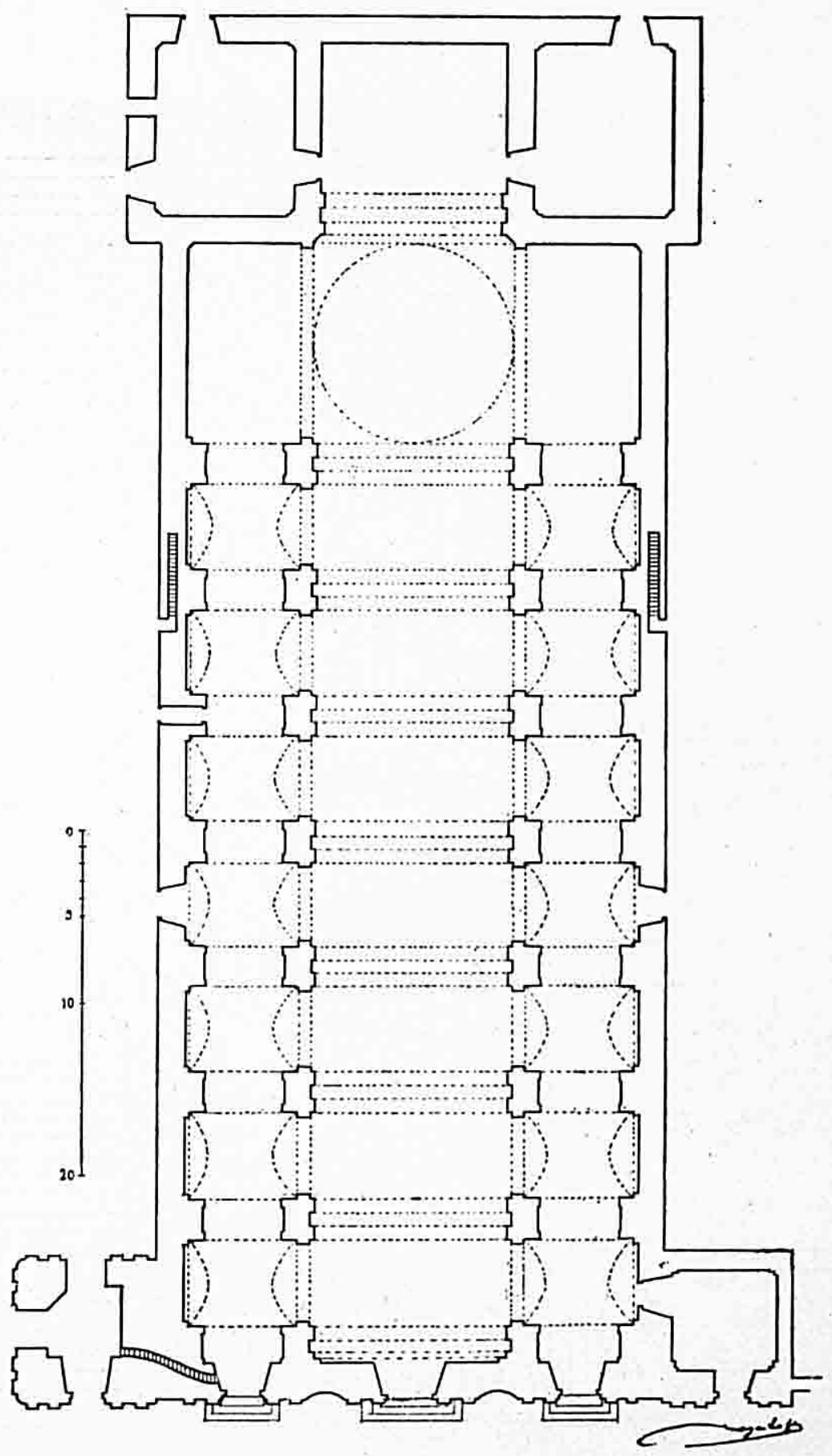

Foto 28 - Reconstituiçāo da igreja de Sāo Miguel. Como o autor procura. reconstituir a concepcâo original do arquiteto que a projetou. Planta. 


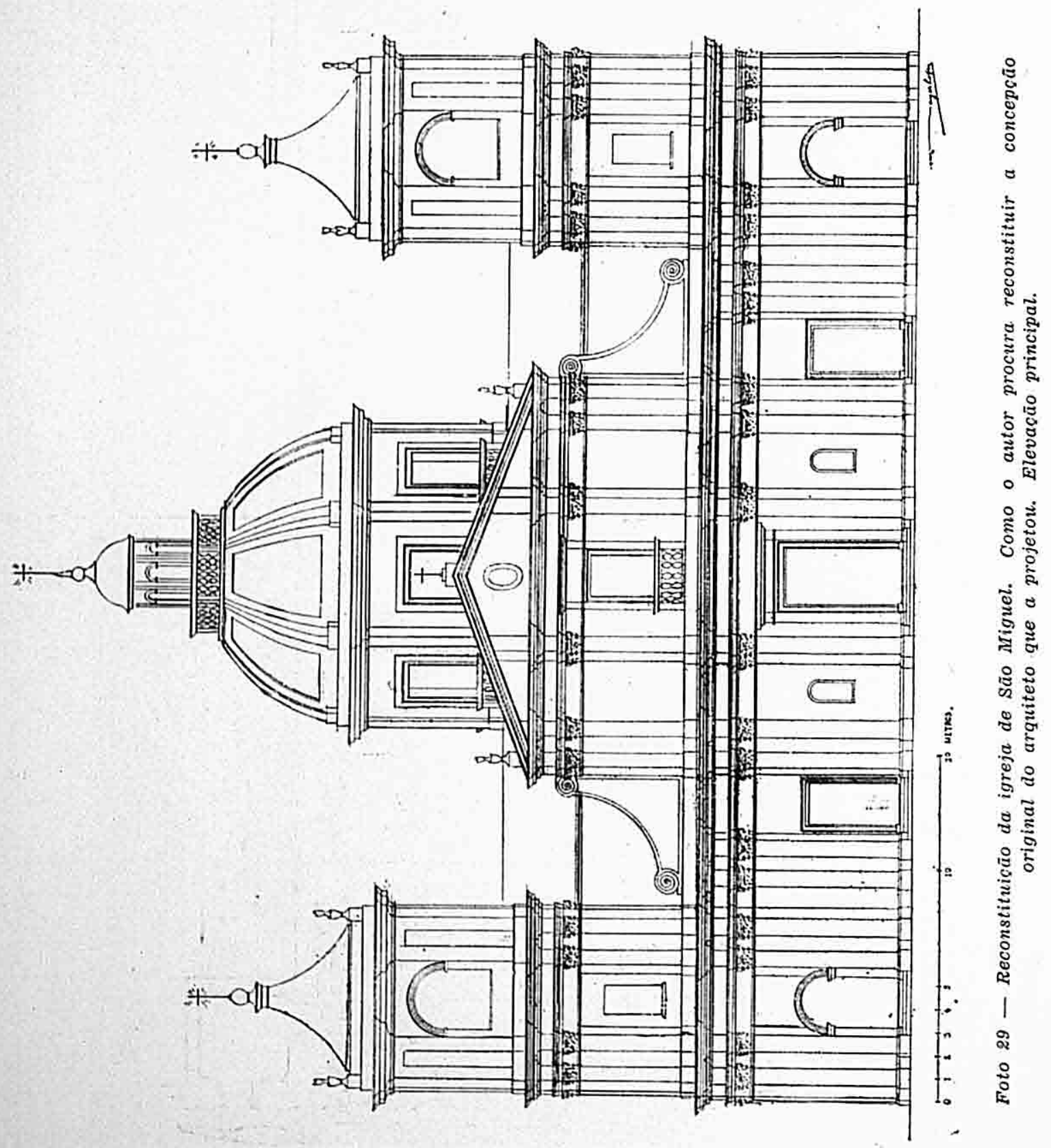




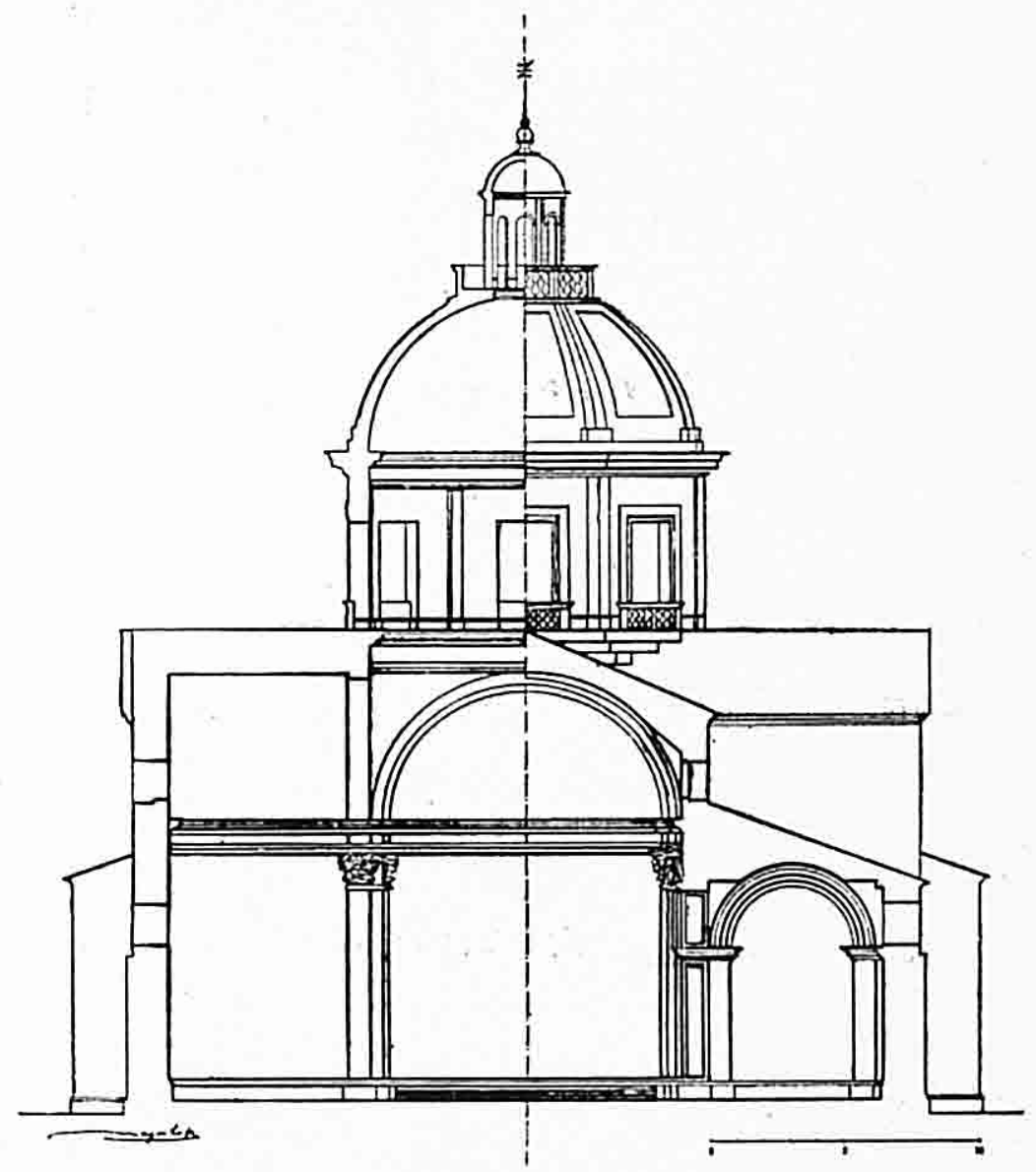

Foto so - Reconstituiçāo da igreja de São Miguel. Como o autor procura reconstituir a concepcāo original do arquiteto que a projetou. Secçāo transversal. 


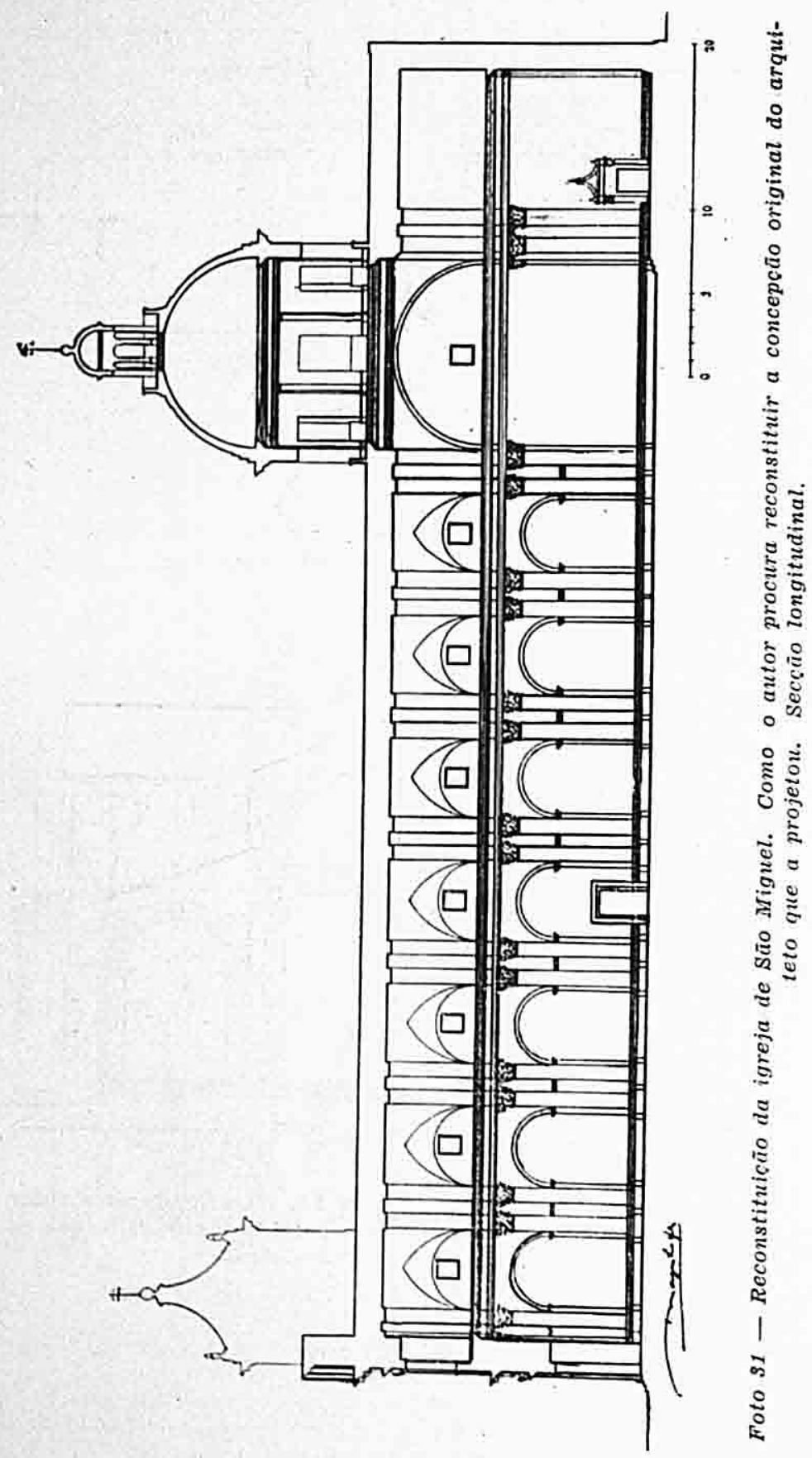



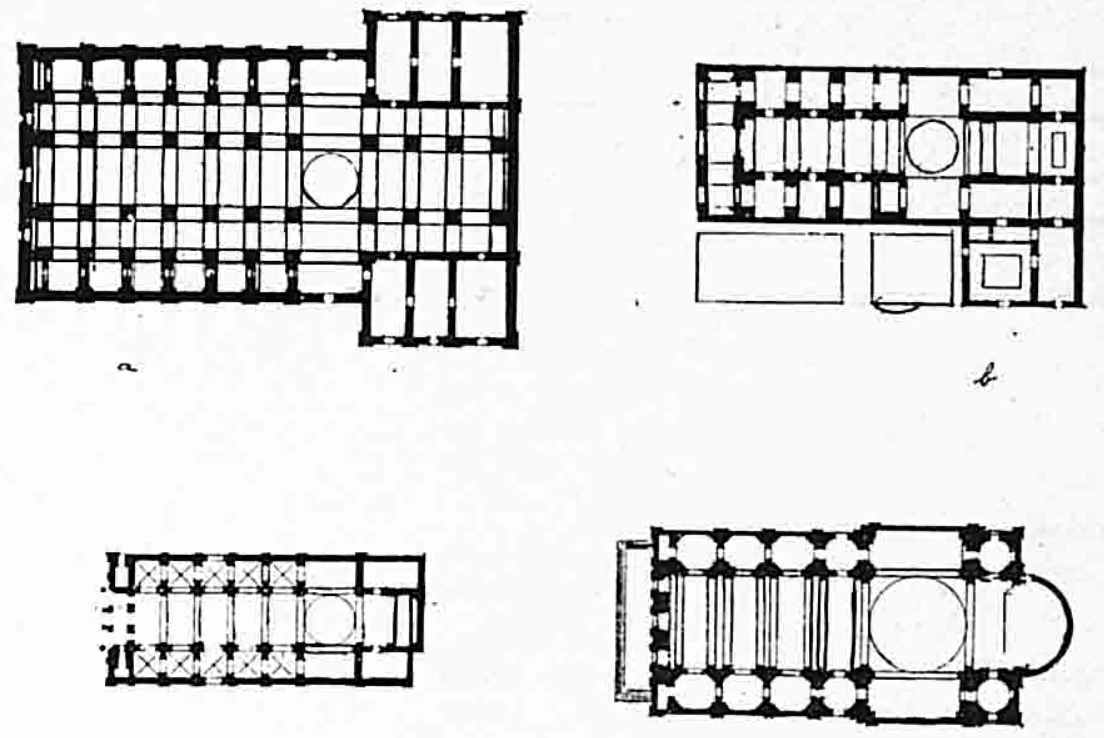

$c$

$\alpha$
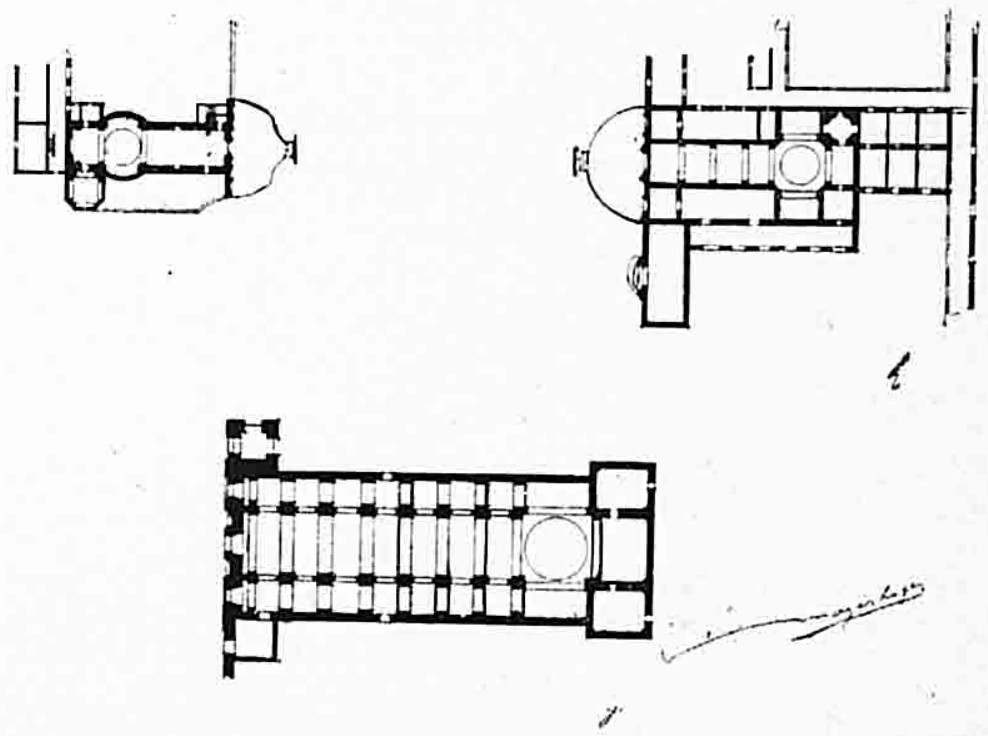

Foto 32 - Plantas comparativas: a) Catedral de Buenos-Aires, com a primitiva fachada; b) Catedral de Córdoba; c) igreja de San Ignacio em Buenos-Aires; dQ igreja do Gesú, em Roma; e) igreja de Alta Gracia, em Córdoba; f) igreja de Santa Catalina, em Córdoga; g) igreja de São Miguel das Missōes. 

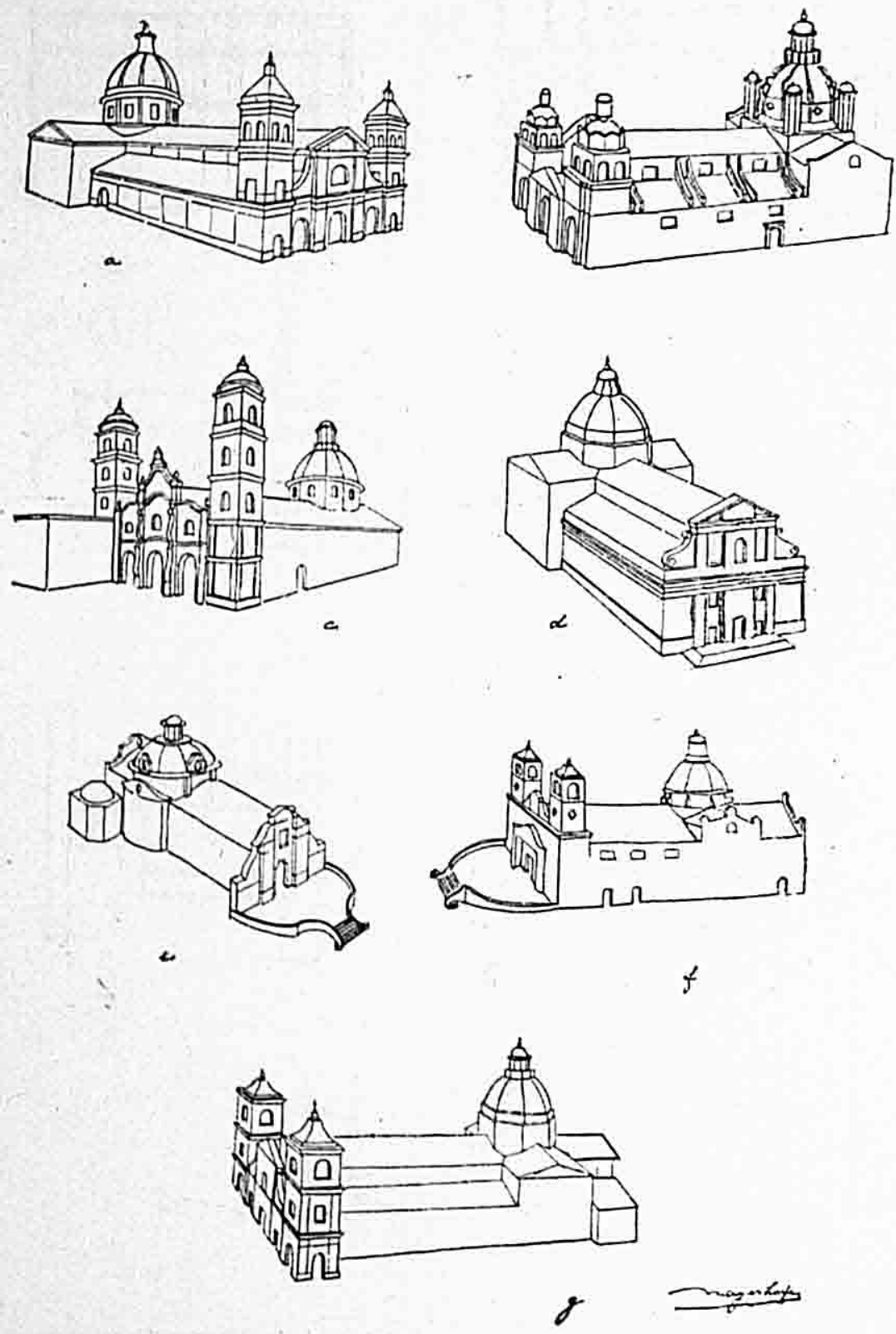

Foto $s s$ - Estudo comparativo de plástica geral. 

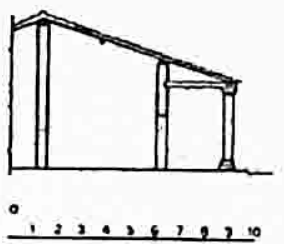

$12,13,12,10$

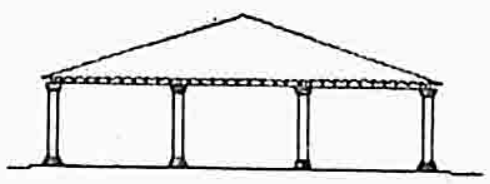

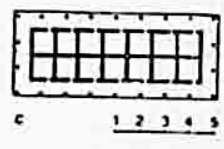

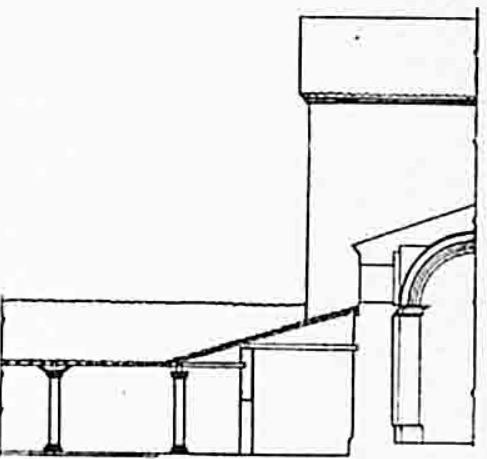

$d$ $12,4,1,1,10$
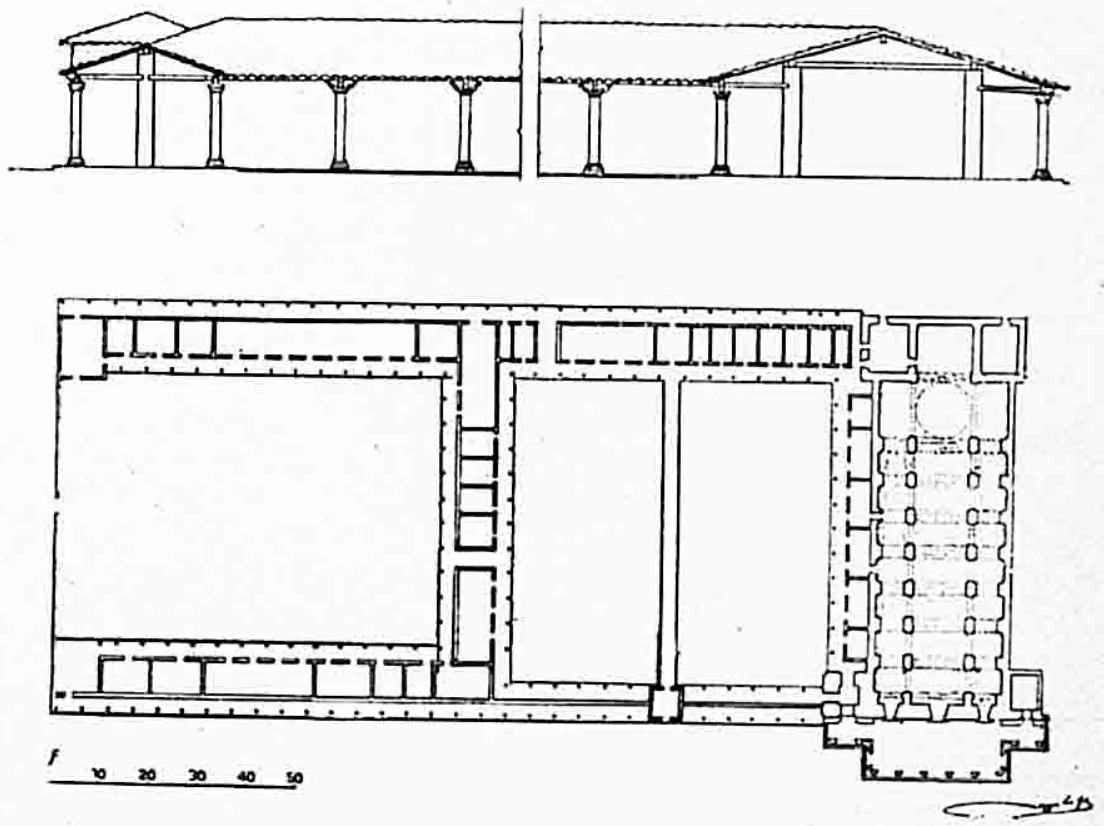

Foto 34 - Reconstiluição do Povo de Sũo Miguel: a) casa dos indios, seccūo transversal; b) casa dos indios, fachada; c) casa dos indios planta; d) Colégio dos Padres, seccão transversal; e) Colégio dos Padres, seccão longitudinal; f) Colégio dos Padres, planta. 